January 2019

\title{
An Evolutionary Theory of Administrative Law
}

Karrigan S. Bork

McGeorge School of Law

\section{Recommended Citation}

Karrigan S Bork, An Evolutionary Theory of Administrative Law, 72 SMU L. REV. 81 (2019)

https://scholar.smu.edu/smulr/vol72/iss1/10

This Article is brought to you for free and open access by the Law Journals at SMU Scholar. It has been accepted for inclusion in SMU Law Review by an authorized administrator of SMU Scholar. For more information, please visit http://digitalrepository.smu.edu. 


\title{
An Evolutionary Theory of Administrative LAW
}

\author{
Karrigan S. Börk*
}

\begin{abstract}
Law evolves to accommodate change-this is axiomatic in most academic legal traditions. But in the era of the administrative state, with congressional gridlock and a judiciary hesitant to address policy questions, evolution of statutory law has become much more difficult. This leads to pent up demand for change in legal regimes. If the legislature and the courts cannot provide an outlet for this pressure, where does it go? How does the law continue to change? Although other scholars have looked to agencies as engines of legal change, we lack a theoretical framework to understand how that change happens. I argue that an evolutionary framework provides an informative model for understanding administrative legal change.

I provide three case studies that demonstrate the administrative evolution of the Endangered Species Act. In spite of tremendous advances in conservation, fundamental changes in scientists' understanding of human impacts on the natural world, and increasingly strident clashes over private property rights and endangered species, the Act has remained largely unchanged for the last thirty-five years. In a functioning legislative system, the Act would have been amended to accommodate many of these changes. Instead, the case studies show a mechanism of legal change through agency action analogous to the mechanisms underlying biological evolution.

Other commentators have argued the administrative state stymies evolution of the law, but this research contradicts that view. The evolution of the law through administrative action may even reduce statutory or judicial evolution of the law. Applying an evolutionary framework to administrative actions creates a theory of administrative evolution of the law, placing administrative analysis within the long tradition of evolutionary approaches to legal change. In contrast to traditional normative theories of administrative law, an evolutionary approach focuses not on why administrative law changes, but rather on how that change progresses over time. This theory of administrative evolution of the law also casts new light on a

* Visiting Assistant Professor of Law, University of the Pacific, McGeorge School of Law. Ph.D. in Ecology (Conservation Biology), U.C. Davis, J.D., Stanford Law School, B.A. in Environmental Policy and B.S. in Biology, University of Kansas. The author would like to thank Robin K. Craig, Utah S.J. Quinney College of Law; his McGeorge Colleagues Frank Gevurtz and Stephen Cody; and his research assistants, Casey Shorrock and Benjamin Tagert.
\end{abstract}


host of normative questions, from the role of judicial review to improvements in agency decision-making. Considering administrative actions within the broader context of the legal evolution promises a fruitful approach to analyzing administrative law.

\section{TABLE OF CONTENTS}

\section{LAW EVOLVES. WHAT HAPPENS WHEN IT}

CAN'T?

A. Situating the Evolutionary Approach in the

Existing Literature ........................ 86

II. THE APPROACH AND STUDY SYSTEM ........... 91

A. Evolutionary Approaches to Legal Change .... 91

1. Legal Variation, Selection, and Inheritance........ 93

2. Identifying Evolutionary Change............... 97

B. The ESA as a Study System.................... 99

1. Introduction to the ESA ..................... 99

2. The Case for the ESA as a Study in Administrative Evolution .............................. 101

III. ADMINISTRATIVE EVOLUTION OF THE ENDANGERED SPECIES ACT ................. 105

A. Evolution of the Species Definition ............. 105

1. Statutory Definition of Species ................ 106

2. Early DPS Listings ........................ 107

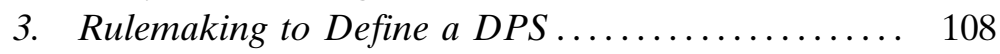

4. Steelhead/Rainbow Trout DPS Controversy....... 110

5. Evidence for Legal Evolution from Species Definitions ............................. 114

B. Evolution of the Safe Harbor Program without a Statutory Framework ............. 116

1. Political and Scientific Pressure ............... 116

2. Safe Harbor Inception ...................... 119

3. Evidence for Legal Evolution from the Safe Harbor Program ................................ 120

C. Evolution of Experimental Populations ......... 124

1. Pitfalls of Experimental Populations ............ 125

2. Changing the Experimental Populations Requirements......................... 126

3. Evidence for Legal Evolution from the Experimental Population Reintroductions ........ 129

IV. PRACTICAL IMPLICATIONS OF THE THEORY OF ADMINISTRATIVE EVOLUTION OF THE LAW .... 130

V. CONCLUSION .............................. 138 


\section{LAW EVOLVES. WHAT HAPPENS WHEN IT CAN'T?}

$\mathrm{L}$ AW evolves. ${ }^{1}$ Law evolves to accommodate changes in societal goals, ${ }^{2}$ physical conditions,${ }^{3}$ cultural norms,${ }^{4}$ technology, ${ }^{5}$ and scientific understanding. ${ }^{6}$ The common law evolves via judicial decisions, constitutional law via amendment and judicial interpretation, and statutory law via legislative revisions and judicial interpretation. This understanding of legal change is axiomatic, ${ }^{7}$ advanced by scholars from Aristotle, Montesquieu, and Burke, ${ }^{8}$ to Justice Oliver Wendell Holmes. ${ }^{9}$

Evolutionary stories abound in the legal literature. Paradigmatic examples appear in water law (evolution of water rights),${ }^{10}$ land use (evolution

1. See Peter Stein, Legal Evolution: The Story of an Idea 125-27 (Cambridge Univ. Press 1980) (tracing the replacement of the natural law approach with the evolutionary law approach to jurisprudence).

2. See, e.g., U.S. Const. pmbl. ("We the People of the United States, in Order to form a more perfect Union, establish Justice, insure domestic Tranquility, provide for the common defence, promote the general Welfare, and secure the Blessings of Liberty to ourselves and our Posterity, do ordain and establish this Constitution for the United States of America.") (emphasis added).

3. John G. Sprankling, Property Law for the Anthropocene Era, 59 ArIz. L. Rev. 737, 744 (2017) ("It is axiomatic that physical conditions, such as geography and climate, influence how law evolves.").

4. See, e.g., Trop v. Dulles, 356 U.S. 86, 101 (1958). Chief Justice Earl Warren said: "The [Eighth] Amendment must draw its meaning from the evolving standards of decency that mark the progress of a maturing society." Id.

5. Shaffer v. Heitner, 433 U.S. 186, 202 (1977) (noting that "[t]he advent of automobiles, with the concomitant increase in the incidence of individuals causing injury in States where they were not subject to in personam actions under Pennoyer, required further moderation of the territorial limits on jurisdictional power.").

6. See, e.g., Holly Doremus, The Endangered Species Act: Static Law Meets Dynamic World, 32 Wash. U. J.L. \& PoL'y 175, 213 (2010).

7. E. Donald Elliott, The Evolutionary Tradition in Jurisprudence, 85 Colum. L. REv. 38, 38 (1985) ("Today the idea that law 'evolves' is so deeply ingrained in AngloAmerican legal thought that most lawyers are no longer even conscious of it as a metaphor. We speak of the law 'adapting' to its social, cultural, and technological environment without the slightest awareness of the jurisprudential tradition we are invoking.").

8. Id. at 39 n. 4 .

9. Oliver R. Goodenough, Cultural Replication Theory and Law: Proximate Mechanisms Make a Difference, 30 VT. L. REv. 989, 991 (2006) (noting that "[o]ne of the most noted proponents [of an evolutionary approach] in the U.S. tradition is Oliver Wendell Holmes. Evolutionary thinking is a strong theme in The Common Law and an explicit one in Law in Science and Science in Law."); see also Oliver Wendell Holmes, The Common LAw 5 (Mark DeWolfe Howe ed., 1963) ("The life of the law has not been logic: it has been experience. The felt necessities of the time, the prevalent moral and political theories, intuitions of public policy, avowed or unconscious, even the prejudices which judges share with their fellow-men, have had a good deal more to do than the syllogism in determining the rules by which men should be governed.").

10. Joseph W. Dellapenna, United States: The Allocation of Surface Waters, in THE Evolution of the LaW and Politics of Water 189, 189 (Joseph W. Dellapenna \& Joyeeta Gupta eds., 2009) (observing that "[t]he law of water allocation in the United States provides examples of how water law evolves in response to differing patterns of hydro-geological availability of water and of demand for water."); see Coffin v. Left Hand Ditch Co., 6 Colo. 443, 447 (1882) (remarking, on the riparian rights doctrine, that "[i]mperative necessity, unknown to the countries which gave it birth, compels the recognition of another doctrine in conflict therewith."). 
of fencing in/fencing out laws),${ }^{11}$ family law (evolution of the common law tort of seduction), ${ }^{12}$ torts (evolution of the economic loss rule), ${ }^{13}$ corporate law (evolution of the corporate form),${ }^{14}$ constitutional law (evolution of due process requirements), ${ }^{15}$ and many other fields. ${ }^{16}$ What drives this legal evolution is an area of intense scholarly debate, with various academic traditions advancing ideas from law as a reflection of evolving society to economic efficiency, ${ }^{17}$ but the legal academy accepts that law adapts to changing conditions.

Evolution of the law is something more specific than change over time. ${ }^{18}$ An evolutionary approach explicitly analogizes the process of legal change in reaction to environmental change to the biological theory of evolution. ${ }^{19}$ As in biological evolution, an evolving legal system builds itself over time, through rounds of lawmaking, with lawmakers choosing laws from among many possible variants, more "fit" approaches surviving and producing new variations, which inherit some characteristic from prior generations of law. ${ }^{20}$ This adaptation of the law over time is thus "an emergent property which spontaneously arises through the interaction of simple components": variation, selection, and inheritance. ${ }^{21}$

But what happens when a law cannot evolve? When a statute is hidebound by legislative divisions and so cannot change, despite radical changes in relevant science and technology, physical setting, societal needs, and cultural norms? Consider Eskridge and Ferejon's Super-Statute Theory. ${ }^{22}$ They highlight a class of federal "super statutes," which become foundational to how the public perceives the governing structures and thus resist legislative efforts at reform. ${ }^{23}$ Examples include the Civil Rights Act of 1964, the Federal Arbitration Act (FAA) of 1926, and

11. See Bernhard Grossfeld, Geography and Law, 82 Мich. L. Rev. 1510, 1515-18 (1984).

12. See M.B.W. Sinclair, The Use of Evolution Theory in Law, 64 U. DET. L. Rev. 451, 459-61 (1987).

13. See Anthony Niblett, Richard Posner \& Andrei Shleifer, The Evolution of a Legal Rule, 39 J. Legal Stud. 325, 354 (2010).

14. See Giuseppe Dari-Mattiacci et al., The Emergence of the Corporate Form, 33 J.L. ECON. \& ORg. 193, 193-94 (2017).

15. See Lawrence Rosenthal, Does Due Process Have an Original Meaning? On Originalism, Due Process, Procedural Innovation . . . and Parking Tickets, 60 OKLa. L. REV. 1, 52 (2007).

16. Elliott, supra note 7, at 45-62.

17. See Herbert Hovenkamp, Evolutionary Models in Jurisprudence, 64 TEx. L. REv. 645,646 (1985).

18. See id. at 647 ("Evolutionary jurisprudence refers only to those jurisprudential theories that explicitly focus on legal change, or that make use of a particular model to explain how legal change occurs.").

19. See Elliott, supra note 7 , at 39.

20. See Donald T. Hornstein, Complexity Theory, Adaptation, and Administrative Law, 54 Duke L.J. 913, 921 (2005).

21. J.B. Ruhl, The Fitness of Law: Using Complexity Theory to Describe the Evolution of Law and Society and Its Practical Meaning for Democracy, 49 VAND. L. Rev. 1407, 1442 (1996) (citing James Gleick, Chaos: Making a New Science 339 (1987)).

22. William N. Eskridge, Jr. \& John Ferejohn, Super-Statutes, 50 DukE L.J. 1215, 1215-17 (2001).

23. See id. at 1229, 1237, 1260-61. 
the Endangered Species Act (ESA) of 1973. ${ }^{24}$ Super statutes "penetrate deeply into American norms or institutional practice" and become unchanging monoliths in the legal landscape. ${ }^{25}$ Assuming law must by its nature evolve to adapt to changing conditions, these super statutes should create pent up demand for legal evolution-a growing need for the law to adapt to meet changing conditions. ${ }^{26}$

Some may point to the courts as an outlet for these evolutionary pressures, recognizing their longstanding role in interpreting statutes and the common law in the light of "[t]he felt necessities of the time." ${ }^{27}$ Certainly, courts could fulfill an evolutionary role in administrative law, but the current form of judicial review of agency decision-making limits the courts' role. ${ }^{28}$ When undertaking arbitrary and capricious review of agency action under the Administrative Procedure Act (APA), ${ }^{29}$ for example, a court must not "substitute its judgment for that of the agency." 30 Instead, the reviewing court determines whether the agency acted within its authority, whether its action was "arbitrary, capricious, an abuse of discretion, or otherwise not in accordance with law," 31 and, finally, whether the agency "action followed the necessary procedural requirements." 32 Likewise, when reviewing agency interpretations of the law under Chevron, the reviewing court's analysis begins by determining whether Congress spoke directly to the issue at hand, and, if not, then proceeds by deferring to the agency's interpretation if it "is based on a permissible construction of the statute." 33 When applying Chevron, "the court does not simply impose its own construction on the statute." 34 " "Congress, when it left ambiguity in a statute' administered by an agency, 'understood that the ambiguity would be resolved, first and foremost, by the agency, and desired the agency (rather than the courts) to possess whatever degree of discretion the ambiguity allows." 35 "The responsibility for assessing the wisdom of ... policy choices and resolving the struggle between competing views of the public interest are not judicial ones: 'Our Constitution vests such responsibilities in the political branches." 36 Moreover, when a court does find that an agency has violated the APA or misinterpreted a statute, the proper remedy is generally to remand to the agency for re-

24. Id. at $1242-43$.

25. Id. at 1215 .

26. Or, perhaps, these super statutes are able to remain unchanging because most evolution of the law has moved into the administrative state.

27. Holmes, supra note 9 , at 5 .

28. See Douglas H. Ginsburg \& Steven Menashi, Our Illiberal Administrative Law, 10 N.Y.U. J.L. \& LIBERTY 475, 478-79 (2016).

29. 5 U.S.C. $\$ 706$ (2012).

30. Citizens to Preserve Overton Park, Inc. v. Volpe, 401 U.S. 402, 416 (1971).

31. 5 U.S.C. $\$ 706(2)(A)(2012)$.

32. Citizens to Preserve Overton Park, 401 U.S. at 417.

33. Chevron, U.S.A., Inc. v. Nat. Res. Def. Council, Inc., 467 U.S. 837, 843 (1984).

34. Id.

35. City of Arlington v. FCC, 569 U.S. 290, 296 (2013) (citing Smiley v. Citibank, 517 U.S. 735, 740-41 (1996)). (1978)).

36. Chevron, 467 U.S. at 865-66 (quoting Tenn. Valley Auth. v. Hill, 437 U.S. 153, 195 
consideration, not for the court to engage in even low-level decision-making. ${ }^{37}$ In sum, then, a reviewing court may not substitute its judgment for that of the agency, may not impose a better reading of a statute on an agency, and may not fashion its own solution when an agency errs. Within these constraints, although the judiciary can reject an agency's changes in the law, the judiciary's ability to effectuate its own evolution of the law is severely limited.

On this understanding, then, both the legislatures and the courts have largely abdicated their roles in evolving some major statutes. Over time, this leads to pent up demand for change in these regimes. Where and how does this evolutionary pressure find release?

This article theorizes that administrative law adapts to evolutionary pressure through a process analogous to biological evolution, mediated by administrative agencies. This analytical framework offers significant lessons about the administrative state. By way of example, this article shows that the National Marine Fisheries Service (NMFS) and the U.S. Fish and Wildlife Services (FWS, together, the Services), the administrative agencies charged with implementation of the Endangered Species Act, have taken over many of the traditional legislative and judicial roles in evolving the law. The process of change in the Act over time mimics the processes at play in biological evolution.

\section{A. Situating the Evolutionary Approach IN THE EXISTING Literature}

Analyzing administrative actions as a form of evolutionary change is a relatively unexplored theoretical approach to administrative law, but the scholarly field of administrative law is a busy one. In this crowded field, it is essential to establish which ideas in this article are new and which are not.

First, this article's recognition of administrative agencies as the dominant realm for legal action is not new. While the legal literature is largely devoid of evolutionary analysis of administrative legal change, the literature recognizes administrative agencies' important role in legal change. ${ }^{38}$ Prominent authors working in this realm include J.B. Ruhl, ${ }^{39}$ Jody Free-

37. See, e.g., Sure-Tan, Inc. v. NLRB, 467 U.S. 883, 905 (1984) (remanding an invalid rulemaking or agency decision to the agency for reconsideration "best respects the congressional scheme investing the Board and not the courts with broad powers to fashion remedies that will effectuate national labor policy.").

38. See, e.g., Jud Mathews, Minimally Democratic Administrative Law, 68 Admin. L. REv. 605, 606-07 (2016) ("The volume of substantive policy choices made by modern agencies in the United States is simply staggering."). For several good environmental law examples, see the recent collection of articles on resilience and the law including, Barbara Cosens, Lance Gunderson, \& Brian Chaffin, Introduction to the Special Feature Practicing Panarchy: Assessing legal flexibility, ecological resilience, and adaptive governance in regional water systems experiencing rapid environmental change, 23(1) ECOLOGY \& Soc'y 4, 9 (2018).

39. J.B. Ruhl \& James Salzman, Mozart and the Red Queen: The Problem of Regulatory Accretion in the Administrative State, 91 GEo. L.J. 757, 762 (2003); Robin Kundis Craig \& J.B. Ruhl, Designing Administrative Law for Adaptive Management, 67 VAND. L. REv. 1 
man and Jim Rossi, ${ }^{40}$ Emily Meazell, ${ }^{41}$ Robin Craig, ${ }^{42}$ and many, many others. ${ }^{43}$ This article does not add much to this well-established view of the role of administrative agencies in our modern world, although it does explicitly make the case that the locus of legal change now lies within the administrative realm. But this is not its primary focus; instead, this article presents a workable theory for making sense of all of this administrative legal change. This article is about how change within this administrative realm occurs, given administrative law's rise to prominence as the new medium for most legal action.

Second, this article is not the first article to consider biological evolution as a framework for some forms of legal change. Prominent scholars using this approach include E. Donald Elliott, ${ }^{44}$ M.B.W. Sinclair ${ }^{45}$ Herbert Hovenkamp, ${ }^{46}$ J.B. Ruhl, ${ }^{47}$ and Ellen E. Sward. ${ }^{48}$ These scholars, however, have focused on legislative and judicial evolution, not administrative evolution. The evolutionary theory of administrative law advocated here updates the prior work for the administrative age. Viewing administrative law as a medium for the continuing evolution of the law places administrative legal change squarely in a long tradition of legal evolution. Moreover, an evolutionary jurisprudence provides a rich foundation for analyzing administrative decisions and decision-making. ${ }^{49}$ "[T]here is a connection between an evolutionary jurisprudence and legal scholarship which is at once constructive and creative, critical and vigorous .... This lays the jurisprudential foundation for the work of scholars like Holmes, Corbin, and Wigmore, work which is both critical and creative." 50 Bringing a similar perspective to administrative lawmaking should prove similarly useful.

Third, advancing a broad theory for administrative law is not new, although the focus of this theory on the way administrative law changes is unusual. Most theories of administrative law currently in vogue focus on

(2014); J.B. Ruhl, Ecosystem Services and the Clean Water Act: Strategies for Fitting New Science into Old Laws, 40 EnVTL. L. 1381 (2010).

40. Jody Freeman \& Jim Rossi, Improving Interagency Coordination in Shared Regulatory Space, 38 Admin. L. Reg. L. News 11, 11 (2013).

41. Emily Hammond Meazell, Deference and Dialogue in Administrative Law, 111 Colum. L. Rev. 1722, 1729-30 (2011).

42. Craig \& Ruhl, supra note 39, at 18.

43. See, e.g., Hannah Gosnell et al., Transforming (perceived) rigidity in environmental law through adaptive governance: a case of Endangered Species Act implementation, 22(4) ECOLOGY \& SoC'y 42 (2017).

44. Elliott, supra note 7, at 38.

45. Sinclair, supra note 12 , at $451-52$.

46. Hovenkamp, supra note 17 , at 645.

47. Ruhl, supra note 21, at 1408-09.

48. Ellen E. Sward, Justification and Doctrinal Evolution, 37 ConN. L. REv. 389, 392 (2004) (collecting citations).

49. Elliott, supra note 7, at 93 ("The striking thing about the scholars who have shared an evolutionary approach to jurisprudence is that they have been among America's most creative legal scholars.").

50. Id. at 93-94. 
justifying or invalidating the administrative state writ large ${ }^{51}$ and are theories of agency legitimacy, not descriptive theories of change. The major theories du jour-most notably the "political control" model ${ }^{52}$ and the "deliberative model," 53 and older models like the "expertise model," 54 along with the many critiques of these models based on public choice theory, anti-majoritarianism, accountability, agency capture, nondelegation, overwhelming bureaucracy, and rule of law ${ }^{55}$-focus primarily on normative debates about agencies and the role of the court in constraining agency actions. ${ }^{56}$ In contrast, the evolutionary approach to administrative law advocated here is a theory of change, concerned with how administrative agencies change the law over time, how those changes are constrained, and what this model of administrative legal change reveals. Few other scholars suggest a theory with this focus. ${ }^{57}$ Because of its focus on explaining administrative changes in the law, an evolutionary theory of administrative law is not inconsistent with other models of administrative legal change, but rather provides a theoretical overlay to those models that shifts the focus to agency outputs and away from agency legitimacy and judicial review. The Supreme Court itself noted the value of an evolutionary approach for administrative rulemaking: "[ $t$ ]he use by an administrative agency of the evolutional approach is particularly fitting." 58 Although the focus here lies on understanding agency actions, this theory carries significant normative implications for traditional notions of political accountability, authority, and judicial deference to agency decision.

Fourth and finally, what is truly new in this article is the explicit analysis of a biological evolutionary framework as applied to administrative legal change. It is surprising that this is the first explicit consideration of the applicability of an evolutionary framework in this context. As described, many authors use evolution as a metaphor to describe legal change generally, and many authors have debated the applicability of the

51. Many of these approaches fit nicely into the red light/green light dichotomy, long used in international law circles. See Carol Harlow \& Richard Rawlings, LAw AND Administration 2 (Herbert S. Marks 1984). But for some reason, these approaches are less in vogue among United States scholars. See Alfred C. Aman, Jr., Administrative Law in a Global Era: Progress, Deregulatory Change, and the Rise of the Administrative Presidency, 73 Cornell L. Rev. 1101, 1128 (1988).

52. See Kathryn A. Watts, Proposing a Place for Politics in Arbitrary and Capricious Review, 119 YALE L.J. 2, 38 (2009) (describing the rise to dominance of the political control model of administrative legitimacy).

53. See Glen Staszewski, Political Reasons, Deliberative Democracy, and Administrative Law, 97 Iowa L. Rev. 849, 858 (2012).

54. Watts, supra note 52, at 33.

55. See, e.g., Richard A. Epstein, Why the Modern Administrative State Is Inconsistent with the Rule of Law, 3 N.Y.U. J.L. \& LiberTy 491, 495 (2008).

56. No recent surveys of the theories in this field appear to exist. Such a survey is long overdue.

57. But see Aaron L. Nielson, Visualizing Change in Administrative Law, 49 GA. L. REv. 757, 759-60 (2015).

58. NLRB v. J. Weingarten, Inc., 420 U.S. 251, 265 (1975) (quoting NLRB v. SevenUp Co., 344 U.S. 344, 349 (1953)). 
evolution metaphor to that general legal change, but the debate over the applicability of the evolution metaphor to administrative law field is lacking. Many authors also use the term evolution to describe administrative legal change, but in most cases the authors appear to be using it "as simply synonymous with change." 59 A very few articles have used the evolutionary metaphor to elucidate administrative lawmaking, but these articles have done so without first considering whether biological evolution is an informative and applicable approach to understanding administrative law. ${ }^{60}$ The one exception appears to be a brief discussion in a longer piece postulating several "natural laws" of administrative law. ${ }^{61}$ Few other works discussing evolutionary theories of legal development even examine administrative legal change, focusing instead on judicial and legislative mechanisms. Some from outside the community of legal scholars touch on evolutionary approaches to administrative law, ${ }^{62}$ but none of these works explain how administrative law demonstrates the "self-assembly, selection, and emergence" necessary for an evolutionary theory of legal change. ${ }^{63}$ Although some of these works nibble around the edges of such a theory, ${ }^{64}$ they lack a firm theoretical foundation

59. William H. Rodgers, Jr., The Natural Law of Administrative Law, 48 Mo. L. Rev. 101, 105 (1983); see, e.g., Eyal Benvenisti, The Interplay Between Actors as a Determinant of the Evolution of Administrative Law in International Institutions, 68 L. \& CONTEMP. Probs. 319, 322 (2005) (focusing on the development of a system of administrative law, rather than on the mechanisms of legal change within such a system); Richard B. Stewart, Vermont Yankee and the Evolution of Administrative Procedure, 91 HARv. L. REv. 1805, 1805 (1978) (arguing that the Vermont Yankee decision stopped the development of new procedural requirements for administrative agencies). Many similar sounding articles argue for a sociobiological approach to law making, but do not address mechanisms of legal change. See, e.g., Owen D. Jones, Evolutionary Analysis in Law: An Introduction and Application to Child Abuse, 75 N.C. L. REv. 1117, 1117 (1997) (exploring "the implications for law of evolved behavioral predispositions in humans").

60. See, e.g., J.B. Ruhl, The Coevolution of Administrative Law with Everything Else, 28 FlA. ST. U. L. REv. 1, 2 (2000) (discussing the ongoing interplay between administrative law and environmental law); 1 William H. Rodgers, Jr., Environmental Law: Air AND WATER, at vi (1986); Robert Charles Clark, The Morphogenesis of Subchapter C: An Essay in Statutory Evolution And Reform, 87 YALE L.J. 90 (1977) (acknowledging that administrative change has played an important role in the evolution of corporate tax culture, albeit without extensively examining administrative legal change); William H. Rodgers, Jr., Where Environmental Law and Biology Meet: Of Pandas' Thumbs, Statutory Sleepers, and Effective Law, 65 U. Colo. L. Rev. 25, 56-60 (1993); William H. Jr. Rodgers, The Evolution of Cooperation in Natural Resources Law: The Drifter/Habitue Distinction, 38 U. Fla. L. Rev. 195 (1986); see also Mark C. Niles, Punctuated Equilibrium: A Model for Administrative Evolution, 44 J. Marshall L. Rev. 353, 359-60 (2011) (exploring the idea of rapid change in administrative law over a short period in response to outside events, albeit not using an evolutionary approach to explain the change); Joseph A. Grundfest, Punctuated Equilibria in the Evolution of United States Securities Regulation, 8 STAN. J.L. Bus. \& Fin. 1, 1 (2002) (taking the same approach).

61. Rodgers, supra note 59, at 105.

62. See, e.g., Rachel Hilliard, Conflicting Views: Neoclassical, Porterian, and Evolutionary Approaches to the Analysis of the Environmental Regulation of Industrial Activity, 38 J. Econ. Issues 509 (2004); Bruce L. Benson, Regulatory Disequilibrium and Inefficiency: The Case of Interstate Trucking, 15 Rev. Austrian ECons. 229 (2002).

63. Hornstein, supra note 20, at 921.

64. Hovenkamp, supra note 17 , at 650 ("The high points of the great Darwinian evolutionary tradition in jurisprudence were produced by people who no longer debated the 
showing the validity of such an approach.

A very few commentators consider administrative change through the lens of adaptive complexity theory, ${ }^{65}$ which shares some perspectives with an evolutionary approach. J.B. Ruhl, one of the few writers to address legal evolution and administrative agencies, has written extensively in this area. Although much of his work focuses on the ability of administrative agencies to adapt to changing regulatory needs, he suggests that the administrative state serves a bar to a truly adaptive or effective system of environmental law. ${ }^{66}$ These important works also do not address a comprehensive theory of administrative legal change. ${ }^{67}$ Professor Donald T. Hornstein has begun to explore complexity theory and administrative change, ${ }^{68}$ but his work has not addressed mechanisms or examples of administrative evolution. ${ }^{69}$ Professor Hornstein provides a helpful overview of some other theoretical approaches to administrative law, and explains how complexity theory can enhance those approaches, but he does not propound a functional theory of administrative evolution. ${ }^{70}$

In some ways, the lack of analysis is unremarkable. In the modern administrative state, we expect the legislature to pass laws that leave the details up to administrative agencies. Perhaps we just expect that agencies will engage in a continuing process of making and remaking laws and that this will follow the broader evolutionary trajectory observed in the law. But the literature does not examine how this happens. Indeed, most scholars seem to simply assume evolution of the law via administrative action, without actually making that framework explicit. ${ }^{71}$

Understanding what evolution of the law means in an administrative setting, however, requires just such an explicit setting out and analysis of the evolutionary theory itself. Only by making underlying assumptions explicit can we open them up for analysis. In a biological context, evolution is a freighted term, carrying a long history and implying myriad mechanisms, strengths, and constraints. Evolution is good at producing

mechanism of natural selection as fueling the theory of evolution. These jurisprudents assumed it, often implicitly.").

65. Hornstein, supra note 20, at 915 (suggesting that "new insights really could be gained by seeing in the administrative state the overarching tendencies of a complex, adaptive system").

66. J.B. Ruhl, Thinking of Environmental Law as a Complex Adaptive System: How to Clean Up the Environment by Making a Mess of Environmental Law, 34 Hous. L. Rev. 933, 939 (1997); J.B. Ruhl \& Harold J. Ruhl, Jr., The Arrow of the Law in Modern Administrative States: Using Complexity Theory to Reveal the Diminishing Returns and Increasing Risks the Burgeoning of Law Poses to Society, 30 U.C. DAvis L. REv. 405, 452 (1997); J.B. Ruhl, Complexity Theory as a Paradigm for the Dynamical Law-and-Society System: A Wake-Up Call for Legal Reductionism and the Modern Administrative State, 45 Duke L.J. 849, 913 (1996).

67. See supra note 66.

68. See, e.g., Hornstein, supra note 20, at 960 ("[R]egulatory environments . . might share the tendencies of complex adaptive systems.").

69. Id. at 921 .

70. See id.

71. See, e.g., Hornstein, supra note 20, at 921; Hovenkamp, supra note 17, at 615; Ruhl, supra note 21, at 1416, 1418. 
some outcomes (populations adapted to the immediate conditions, for example), but very poor at producing other outcomes (globally "best" solutions, predictable outcomes, and changes in traits with weak linkages to reproductive success, for example). How much of this history and context do administrative law scholars imply when we casually mention evolution of administrative rules? How much of the theoretical work around biological evolution could we build on if we bring evolution into administrative analysis in a robust and explicit way? This article begins to address these questions, in hopes that future articles can develop this approach more fully.

Broadly, "[A]dministrative law's complexity makes it hard to see the big picture ... [t] he regulatory state has many moving parts, making it challenging to appreciate how they all fit together, much less how the overall structure is changing[,] or rather, not changing."72 But this kind of broad look is essential to understanding how a body of administrative law changes over time, and an evolutionary theory of administrative law offers the broad perspective that may be useful to others taking a sweeping view of administrative legal change.

Section II of this article validates its approach to legal evolution and choice of study system, the Endangered Species Act. Section III provides case studies of three aspects of the Act: (1) the evolution of the definition of species that may be listed under the Act, based on changes in population science; (2) the evolution of the Safe Harbor Program, based on the burgeoning property rights movement; and (3) the evolution of the experimental population as a mechanism of species reintroduction to better reflect developing societal needs. These case studies demonstrate how administrative changes in the interpretation and execution of the Act reveal a form of legal evolution. Section IV makes tentative normative suggestions based on this evolutionary approach to administrative law. Finally, Section V briefly concludes.

\section{THE APPROACH AND STUDY SYSTEM}

\section{A. Evolutionary Approaches to Legal Change}

Undertaking this inquiry requires a precise definition of evolution of law, lest any change over time in the administration of a statute be swept up in the definition. Not every theory of legal change builds on an evolutionary approach. ${ }^{73}$ Biological evolutionary models require three basic mechanisms: variation, selection acting on that variation, and inheritance of selected traits. ${ }^{74}$ Individuals within a population exhibit variation so

72. Nielson, supra note 57 , at 758 .

73. Elliott, supra note 7, at 39 n.4 ("Many legal writers, including Aristotle, Montesquieu, and Burke, have expressed ideas similar to those in the evolutionary tradition without drawing explicit analogies to the theory of evolution in biology.").

74. Sinclair, supra note 12 , at 454 ("Theories of evolution typically have three basic components: a theory of variation, a theory of selection, and a theory of transmission or retention."). 
that some individuals are a better fit for their environment (variation). The more fit individuals survive to reproduce at a higher rate (selection), and then their more numerous offspring exhibit some of the same traits that made their parents more fit to their environment (inheritance). Lather, rinse, repeat-over time, given a relatively consistent landscape, a population of organisms will evolve toward a higher degree of fitness, better able to survive and reproduce in that environment. This Darwinian evolution produces adaptive changes over generations.

Darwin's approach was revolutionary not merely because he suggested that species evolved over time, but rather because he proposed this set of mechanisms, abstracted from the underlying biology, ${ }^{75}$ that accounted for self-guided adaptation over time. Indeed, even in a world that knew nothing of genes or other mechanisms of inheritance, Darwin could "formulate simple, powerful statements at higher levels of abstraction about the patterns of change that result from these forces." 76

In its infancy, evolutionary theory found more acceptance and led to more development in the social sciences than in biology. The mechanisms producing variation, selection, and inheritance seemed much more selfevident in the social sciences, at least at a broad scale:

The history of ideas ... needed no such mechanism to complete its theory of evolution. The fact that ideas are a product of human creativity, thrown into the cultural pot more-or-less randomly and often created precisely because they are novel, could explain cultural change. Furthermore, both the strength of tradition and inherent human conservatism, which prefers successful old ideas over untried new ones, explained "cultural inheritance" better than any nineteenth century theory of biological inheritance. ${ }^{77}$

The parallels to legal change are unavoidable. Legislatures, courts, creative attorneys, and legal commentators spin out never-ending variations on the law, writing, endorsing, or arguing for new legal rules. ${ }^{78}$ Some of these rules "survive" over time, succeeding based on their ability to meet societal needs. ${ }^{79}$ Success comes in the form of spreading to other jurisdictions, surviving new legal challenges, reducing costs, or achieving the law's own aims. ${ }^{80}$ And the laws proposed by the legal community tend toward variations on existing laws, based on common law constraints, a

75. Elliott, supra note 7, at 90 ("Evolutionary theories ... may be used to describe the nature and direction of changes in a complex phenomenon even though little is known about its constituent parts and the mechanisms connecting them.").

76. Id. Nevertheless, the lack of a mechanistic explanation for Darwinian evolution slowed its acceptance until the rediscovery of Mendelian genetics in 1900. See THE Evolutionary Synthesis: Perspectives on the Unification of Biology x-xi (Ernst Mayr \& William B. Provine eds., 1998). This was until the collision of Mendelism, population genetics, and evolution led to the great synthesis in the 1930s and 1940s, which laid the foundation for most of modern biology. See id. at xii-xiii; Julian Huxley, Evolution: The Modern Synthesis 47 (1942).

77. Hovenkamp, supra note 17 , at 648 .

78. Sinclair, supra note 12 , at $456-58$.

79. Id. at 458 .

80. Id. at 456-58. 
general trend toward legal conservatism, a lack of imagination, or other factors. ${ }^{81}$ In an evolutionary legal framework, the law evolves to become a better and better fit to the needs of society through this iterative process.

At their best, theories of legal evolution draw on the well-developed theories of biological evolution, ${ }^{82}$ while remaining highly cognizant of the myriad differences between the two and the traps these differences lay for the unwary analyst. To bare the bones of the analysis, here follows an explicit discussion of the proposed model of evolution in administrative law. In the evolutionary theory of administrative law proposed here, some of the relatively intangible mechanisms in law for variation, selection, and inheritance can be made more explicit. ${ }^{83}$

\section{Legal Variation, Selection, and Inheritance}

First, variation. Variation in administrative interpretations of the law come from many sources, including the executive and legislative branches and the public, particularly special interest organizations. Agencies are an arm of the executive, and new administrations bring a new perspective on a host of issues committed to agency discretion. "A change in administration brought about by the people casting their votes is a perfectly reasonable basis for an executive agency's reappraisal of the costs and benefits of its programs and regulations." ${ }^{4}$ Congress also brings significant new ideas and political pressure to bear on administrative agencies, often through congressional hearings, creating potential new variations in agency actions. ${ }^{85}$ Further, agencies respond to public demand for rulemakings, whether that demand comes via a petition for rulemaking or a lawsuit, as in Massachusetts v. EPA. ${ }^{86}$ Agencies also seek out new variants by requesting public participation in the administrative process through workshops ${ }^{87}$ or the notice and comment and hearing requirements of the APA and the National Environmental Policy Act (NEPA). ${ }^{88}$ Agencies must meaningfully engage with the public comments they re-

81. Id.

82. Ruhl, supra note 21 , at 1415 ("[W]here legal theory has progressed on the question of evolution of law, this progression is in no small measure a remarkable mirror image of the refinement of evolutionary biology from Darwin to the Ecosystem Age.").

83. See Sinclair, supra note 12, at 454. (1983).

84. Motor Vehicle Mfrs. Ass'n of U.S. v. State Farm Mut. Auto. Ins., 463 U.S. 29, 59

85. FCC v. Fox Television Stations, Inc., 556 U.S. 502, 523 (2009) (“[T]he precise policy change at issue [in FCC v. Fox] was spurred by significant political pressure from Congress.").

86. 549 U.S. 497, 497 (2007). First, "a group of 19 private organizations filed a rulemaking petition asking EPA to regulate greenhouse gas emissions from new motor vehicles under $\S 202$ of the Clean Air Act." Id. at 510 (internal quotation marks omitted). When the agency denied the petition, a collation of petitioners filed suit. See id. at 514 .

87. See, e.g., Maine v. Norton, 257 F. Supp. 2d 357, 378-79 (D. Me. 2003). (2017).

88. See Administrative Procedure Act, 5 U.S.C. § 553(c) (2012); 40 C.F.R. $\$ 1506.6$ 
ceive, ensuring consideration of a wide range of policy variation. ${ }^{89}$ Altogether, these sources produce the rich variation at the heart of administrative evolution of the law.

Second, selection. Selection acts on variation in several ways, selecting the more fit variants for survival. At the outset, this requires determining what makes an administrative interpretation "fit." Just as a fit organism is defined as one that survives and reproduces, a fit administrative interpretation is one that survives to promulgation and beyond, eventually spawning new interpretations that carry the core approach forward..$^{90}$ Selection acts on administrative action in two distinct ways. Ultimately, agencies decide which actions to execute (via rulemakings, policy statements, decisions, and the many other administrative possibilities), and these decisions select those policy variants that will survive. ${ }^{91}$ Courts may also act to eliminate some policy options, through decisions striking down agency actions or statutory interpretations. Finally, the legislature sometimes acts directly to change or call back an agency action, again eliminating some administrative actions. Through agencies, courts, and the legislature, selection pares off less fit administrative interpretations of the law. ${ }^{92}$

More broadly, the agencies, legislature, and to a lesser extent the courts, are responsive to sources of selective pressure that shape their decision-making. Many of the same entities that suggest policy variants also lobby for these options, which shapes administrative decision-making. After the agency promulgates a regulation, the regulation faces ongoing selective political pressure from several sources, including the public,

89. Perez v. Mortg. Bankers Ass'n, 135 S. Ct. 1199, 1203 (2015) (“An agency must consider and respond to significant comments received during the period for public comment.").

90. This risks a tautology in detecting whether administrative evolution of the law does in fact occur. Elliott, supra note 7, at 93. If the best laws are defined as those that are most likely to survive, and the evidence that they are the best is likewise that they have in fact survived, analysis devolves into a Panglossian view of the world, holding that " $\mathrm{t}]$ hings cannot be otherwise than as they are; . . . all is necessarily for the best end." VolTAIRE, CANDIDE 3 (Bonland Liveright, Inc. 1918). But, as discussed below, an evolutionary approach does not presume that the law at present is the best or highest form of the law. Evolution is an emphatically nonteleological process. Hovenkamp, supra note 17, at 671. Evolution produces a tree with many branches, not a path toward a particular pinnacle. Likewise, legal evolution need not produce better, cleaner, or more developed solutions over time. And because the selective legal environment is likely to undergo continuous changes, sometimes in response to changes in the law itself, legal evolution does not move the law toward any particular endpoint. Ruhl, supra note 21 , at 1459-60.

91. This first form of selective pressure - the conscious decisions of the agency about which interpretation to choose-raises a potential pitfall in the comparison to biological evolution. Biological evolution, by its nature, depends on random variation. This is a key component of evolution, separating it from intelligent design or other guided forms of adaptation over time. Species do not choose how they evolve, while regulatory agencies do. Ruhl, supra note 21, at 1450-51. This does not invalidate the evolutionary model for the study of law. Sinclair, supra note 12 , at 456 . The basic machinery of the evolutionary process persists.

92. But see Ruhl, supra note 21, at 1451 ("Fitness of laws, just as for species, is measured in terms of how successful the law is in meeting its goals."). This approach to measuring the fitness of a law does not appear to account for the broader way commentators often discuss the evolution of the law, as a series of changes from one law to the next. 
the legislature via hearings or other communications, from unsuccessful court challenges, and from the rest of the executive branch. When these political pressures mount, they can drive the agency to reverse course and change the action.

Selection, then, comes directly though administrative actions, judicial decisions affecting those actions, and, rarely, legislative changes to administrative actions. It comes indirectly through all the assorted selective pressures that affect these direct selection mechanisms.

Third, inheritance. In biological systems, inheritance has two primary effects: it increases the chances that adaptive traits are maintained in a population and constrains the range of possible adaptions that a new generation of offspring is likely to exhibit. Because the variation in a population springs from (generally) minor alterations in inherited genetic information, each new generation is more or less limited in the potential range of variation it may exhibit. This constraint is termed path dependence-existing traits are a product of selection acting on what came before. ${ }^{93}$ Two mechanisms in administrative law similarly limit the range of variation a given administrative action can exhibit and ensure that successive generations of administrative law are not too far removed from past agency actions: first, statutory limits, and second, challenges to changes in agency practices.

In the primary mechanism, agencies are constrained by the very statutes that give them their power. Agencies are creatures of limited power, able to operate only within the bounds of their organic acts or other legislative devolutions of power. With regard to agency power, "the determinative question is ... what Congress has said it can do." ${ }^{4}$ When a statute provides a definition of a term, for example, an agency can build on that definition, altering it through explication via rulemakings, but they cannot promulgate a definition not "based on a permissible construction of the statute." 95 Similarly, an agency can create a program based on the power it is provided by a statute, but it cannot do so in a way that contravenes the underlying statute. Thus, statutes limit the range of possible variation in administrative rulemakings, and regulatory definitions inherit the limitations of the statute. These are broad constraints that inhere in the power of the agencies themselves.

For the secondary mechanism, courts place some limits on changes from one administrative action to the next, beyond the general trend toward legal conservatism common to all areas of the law.96 "[A]n '[u]nexplained inconsistency' in agency policy is 'a reason for holding an interpretation to be an arbitrary and capricious change from agency prac-

93. Richard R. Nelson, Recent Evolutionary Theorizing About Economic Change, 33 J. ECON. LiterATURE 48, 50-51 (1995) ("[T]he process of evolution is strongly path dependent and there is no unique selection equilibrium. Any 'optimizing' characteristics of what exists therefore must be understood as local and myopic").

94. Civil Aeronautics Bd. v. Delta Air Lines, Inc., 367 U.S. 316, 322 (1961).

95. Chevron, U.S.A., Inc. v. Nat. Res. Def. Council, Inc., 467 U.S. 837, 843 (1984).

96. Sinclair, supra note 12 , at 456-58. 
tice.' An arbitrary and capricious regulation of this sort is itself unlawful." 97 Although precedent imposes no "requirement that all agency change be subjected to more searching review," 98 the Supreme Court does require an agency to provide additional explanation for the change. ${ }^{99}$ Moreover, the Supreme Court has imposed heightened justification requirements for some agency actions that deviate from historic practices. ${ }^{100}$ For instance, when prior policies create reliance interests ${ }^{101}$ and when new actions "rest[] upon factual findings that contradict those which underlay [the agency's] prior policy,"102 the decision faces heightened review. More broadly, the definitive quantitative study of judicial review of agency decisions found that "long-standing agency interpretations prevailed under all deference regimes combined at a much higher rate $(82.3 \%)$ than . . . those that were inconsistent with a prior interpretation $(59.8 \%) . " 103$ This creates a strong incentive for agencies not to deviate markedly from their past practices.

Taken together, these two mechanisms-the statutory constraints on agency actions and the additional requirements imposed on agencies making diametric changes from past agency practices-create a powerful force that fulfills in administrative legal evolution the same functions inheritance fulfills in biological evolution.

Although these three mechanisms (variation, selection, and inheritance) seem to present a plausible setting for the administrative evolution of the law, the precise mechanisms themselves matter less than whether the system functions in a way that achieves an evolutionary result. Darwin's evolution focused on "simple, powerful statements at higher levels of abstraction about the patterns of change that result from these forces," 104 not the mechanisms that permitted evolution. In the same way, when legal scholars "describe legal evolution without defining precisely why some legal doctrines are 'stronger' than others, they are not abusing evolutionary metaphors." 105 Instead, these scholars "use an unique aspect of the power of evolutionary models to make relatively refined statements at an abstract level when little is known about the determinants of specific cases." 106 Getting bogged down in precise details

97. Encino Motorcars, L.L.C. v. Navarro, 136 S. Ct. 2117, 2126 (2016) (citing Nat'l Cable \& Telecomms. Ass'n v. Brand X Internet Servs., 545 U.S. 967, 981 (2005)).

98. FCC v. Fox Television Stations, Inc., 556 U.S. 502, 514 (2004) (emphasis added).

99. The agency must "display awareness that it is changing position." Id. at 515. It must also "show that there are good reasons for the new policy. But it need not demonstrate to a court's satisfaction that the reasons for the new policy are better than the reasons for the old one." Id.

100. See Gillian E. Metzger \& Kevin M. Stack, Internal Administrative Law, Mich. L. REV. 1239, 1307 n.347 (2017).

101. Encino Motorcars, 136 S. Ct. at 2126.

102. See FCC, 556 U.S. at 515; see also Metzger \& Stack, supra note 100, at 1307 n.347.

103. Kent Barnett \& Christopher J. Walker, Chevron in the Circuit Courts, $116 \mathrm{MicH}$. L. REV. 1, 8 (2017).

104. Elliott, supra note 7, at 90.

105. Id. at 91.

106. Id. 
leads to unhelpful wheel-spinning, ${ }^{107}$ not meaningful theories that serve the core function of evolutionary approaches to jurisprudence: to "challenge us to consider human nature, and the relationships between human beings and the environment as they really are." 108 The more important test for an evolutionary theory of administrative law, then, is not whether the system as a whole has identifiable mechanisms for variation, selection, and inheritance (although identifiable mechanisms are certainly a positive), but rather whether the system behaves in a way akin to an evolutionary system.

\section{Identifying Evolutionary Change}

So, then, how can one recognize evolutionary lawmaking? One could simply assume it to be self-evident, ${ }^{109}$ arguably a weak link when building a theory of administrative evolution of the law. Instead, the mechanisms of biological evolution suggest several indicators of evolution. For example, evolution is iterative, usually based on a series of small steps. Evolutionary change, as typically discussed in legal circles, involves changes that make the law more fit in small steps-iterative changes toward improved fitness. Similarly, administrative evolution should exhibit iterative changes in the law in response to selective pressures in the administrative environment. ${ }^{110}$ Administrative actions that exhibit these characteristics provide evidence agencies are enacting evolution of the law.

Further, evolutionary change is unique in that it is path dependent-it must build on and be constrained by prior adaptations. These requirements give rise to certain surprising outcomes that themselves serve as indicators of an evolutionary system. For example, because evolutionary change is iterative and path dependent, it does not necessarily lead to ideal solutions, but rather the best solution given the current arrangement.

Evolution is like a ladybug trying to get to a high point to take off. Ladybugs march in one direction, uphill, until they can no longer go uphill, and then they take off. At best, this gets a ladybug to the highest point in an uphill direction, but it does not guarantee that the ladybug will get to the highest point around. In other words, the ladybug reaches a local maximum, but not necessarily a global one. Uphill marches are efficient for finding the nearest high point, but they are unlikely to lead to the highest high point - where you end up depends entirely on where you start. Similarly, evolution of traits under selection generally progresses

107. Hovenkamp, supra note 17, at 662 (noting the tendency of "Darwinian social science . . . to lapse into dry, complicated, and endless classification schemes.").

108. Elliott, supra note 7, at 94.

109. Hovenkamp, supra note 17 , at 649-50.

110. Ruhl, supra note 21, at 1412 ("The answer is not as simple as pointing out that legislatures pass new legislation, courts decide new case principles, and agencies promulgate new regulations. Those institutions could do that all day long every day and not move the community one iota closer to fitness; indeed, regression into stasis or chaos would be more likely."). For a discussion of contrasts between evolutionary and non-evolutionary paradigms, see Nelson, supra note 93. 
toward higher fitness. Organisms do not evolve to be a perfect fit for their environment, but rather to be the best possible fit given where they are at the start. Even though legal evolution has some human direction, and humans can be more deliberate about their legal wanderings, if evolution describes some significant part of the mechanism of legal change, we should find law occupying local maxima-legal solutions that are the best outcome given the parameters at the start of the evolutionary process, but not necessarily the best possible outcome overall. ${ }^{111}$

Similarly, this aspect of evolution's operation also leads to artifacts like the panda's thumb. Noted biologist Stephen Jay Gould explains that the historical panda's thumb evolved to become part of its paw, unable to function as a normal thumb because the panda did not benefit from having a thumb at that point in its history. ${ }^{112}$ Later, as the panda began to specialize in eating bamboo, it once again required a thumb, but its old thumb was "too specialized for a different function to become an opposable, manipulating digit." 113 Eventually, the panda evolved a sixth digit, a new thumb, from an enlarged wrist bone, allowing it to easily manipulate its bamboo stalks. ${ }^{114}$ In evolution more broadly, a "panda's thumb" refers to something old pressed into service in a new and unexpected way, because previous evolution has precluded more optimal solutions. These mad scrabble solutions are significant evidence of evolution, more so than organisms where all the parts "fit." "Odd arrangements and funny solutions are the proof of evolution-paths that a sensible God would never tread but that natural process, constrained by history, follows perforce." 115 In the evolutionary law context, this is akin to finding legal approaches pressed into service in new or unexpected ways. Professor Sinclair notes "[i]t is not difficult to find the kind of data that illustrate legal evolution.... Whenever one finds a legal fiction, one has found the kind of jury-rigged adaptation that characterizes evolutionary phenomena."116 In an administrative law context, a panda's thumb could be analogous to administrative actions built on shaky or nonexistent statutory footings. Other commentators have observed the role of path dependence in shaping regulations in some legal fields. ${ }^{117}$ Such an action may press a statute into service in a way Congress never intended, because the action must build on the inherited legal framework.

111. Ruhl, supra note 21, at 1411-12.

112. See Stephen J. Gould, The Panda's Thumb: More Reflections in Natural History 24 (1980).

113. Id.

114. Jane Qiu, How the Panda's 'Thumb' Evolved Twice, Nature (Jan. 16, 2017), https://www.nature.com/news/how-the-panda-s-thumb-evolved-twice-1.21300 [http://perma .cc/9JJ9-F28A].

115. Gould, supra note 112 , at 20-21.

116. Sinclair, supra note 12 , at 475 .

117. Hornstein, supra note 20, at 928 ("Other legal scholars are also beginning to use the insights of sensitivity to initial conditions and path dependence to analyze particular areas of statutory and administrative law such as securities law, environmental regulation, and banking law."). 
Ultimately, Professor Elliot suggests "it would be a fundamental mistake to evaluate evolutionary theories of jurisprudence as true or false. ... Instead, we should judge evolutionary jurisprudence as we judge any creation myth, by whether it is useful." 118 This is an instrumentalist approach to understanding evolutionary legal theories, which focuses on whether a theoretical approach yields useful results, not whether it is strictly "true" in some kind of realist sense. He argues "the evolutionary tradition does not dictate a single definite theory of law; at most, an evolutionary approach to law creates a context, a distinctive kind of conversational setting, within which dialogue about law may occur."119 This article endeavors then, not to provide all the evidence necessary to prove up the concept of administrative evolution of the law, but at least enough evidence to provide the ongoing administrative law dialogue with a new and productive conversational setting. This setting does not explain all the reasons agencies do the things they do, but rather it helps to explain the constraints on the way the agencies do those things. As Professor Sinclair noted in his seminal critique of evolutionary approaches to the law, "[i]f all goes well this will throw a new light on the development of an area of the law, how it reached its present state, and how it might change in the future." 120

\section{B. The ESA as a Study System}

\section{Introduction to the ESA}

Congress created the ESA in 1973 to provide for the conservation of ecosystems vital to endangered and threatened species, to conserve the species themselves, and to fulfill the United States' duties under international endangered species treaties. ${ }^{121}$ The Act's significant protections make it "the most comprehensive legislation for the preservation of endangered species ever enacted by any nation." 122 The Act has decreased extinctions, ${ }^{123}$ and listed species are more likely to be improving than declining. ${ }^{124}$ These accomplishments are not without costs: estimates vary from $\$ 3.5$ billion over an eleven-year period to $\$ 3.5$ billion per year. ${ }^{125}$

To garner protection, a species must first be listed as threatened or endangered under Section 4. ${ }^{126}$ Once a species is listed as endangered, it receives the Act's full protection. ${ }^{127}$ Threatened species do not automati-

118. Elliott, supra note 7, at 92-93.

119. Id. at 93 .

120. Sinclair, supra note 12 , at 451 .

121. 16 U.S.C. $\$ 1531$ (b) (2012).

122. Tenn. Valley Auth. v. Hill, 437 U.S. 153, 180 (1978).

123. Mark W. Schwartz, The Performance of the Endangered Species Act, 39 Ann. Rev. Ecology, Evolution \& Systematics 279, 291 (2008).

124. Id. at 292.

125. Randy T. Simmons \& Kimberly Frost, Accounting for Species: The True Costs of the Endangered Species Act, PERC (April 1, 2004), available at https://www.perc.org/wpcontent/uploads/old/esa_costs.pdf.

126. 16 U.S.C. $\$ 1533(\mathrm{~b})(1)(\mathrm{A})(2012)$.

127. Id. $\S 1538(\mathrm{a})(1)$. 
cally receive the same protections but rather only the protections the Services "deem[ ] necessary and advisable to provide for the conservation of such species."128

The protections of the Act are largely bestowed by Sections 7 and 9.129 Section 9 bars the "take" of "any endangered species of fish or wildlife," 130 which is defined very broadly to include "to harass, harm, pursue, hunt, shoot, wound, kill, trap, capture, or collect, or to attempt to engage in any such conduct." 131 With the blessing of the Supreme Court, the Services have further broadened this definition to capture damage to listed species' habitat, by defining harm to "include significant habitat modification or degradation where it actually kills or injures wildlife by significantly impairing essential behavioral patterns, including breeding, feeding or sheltering." 132 The take prohibition applies to "any . . . entity subject to the jurisdiction of the United States," including both state governments and the federal government itself. ${ }^{133}$

The federal government further restricts its own activities through Section 7(a)(2) of the ESA, which requires that "[e]ach Federal agency ... insure that any action authorized, funded, or carried out by such agency ... is not likely to jeopardize the continued existence of any endangered species or threatened species or result in the destruction or adverse modification of [critical] habitat of such species." 134 In order to meet this requirement, agencies are required to consult with the expert Service for any action that "may affect listed species or critical habitat." 135 Based on the consultation, the relevant expert agency will issue a biological opinion $(\mathrm{BiOp})$ determining whether or not the Federal action "is likely to jeopardize the continued existence of listed species or result in the destruction or adverse modification of critical habitat."136 The BiOp provides an incidental take statement (ITS) that exempts any associated take from the Section 9 take prohibitions. ${ }^{137}$ The BiOp and ITS may include mitigation requirements or other conservation measures. ${ }^{138}$

Taken together, Sections 7 and 9 impose significant restraints on both public and private actions that could imperil listed species, subject to the permits and exceptions outlined in Section $10 .{ }^{139}$ Section 9 directly per-

128. Id. $\S 1533(\mathrm{~d})$. FWS has, by default, extended the full protections of the Act to all listed threatened species under its jurisdiction, Endangered and Threatened Wildlife and Plants, 50 C.F.R. $\$ \S 17.40-48$ (2017), while NMFS grants such protection on a species-byspecies basis. Id. $\$ 222.307($ a).

129. 16 U.S.C. $\S \S 1536,1538$ (2012).

130. Id. $\S 1538(\mathrm{a})(1)(\mathrm{B})$.

131. Id. § 1532(19).

132. 50 C.F.R. \& 17.3 (2017); see Babbitt v. Sweet Home Chapter of Cmtys. for a Great Or., 515 U.S. 687, 715 (1995).

133. 16 U.S.C. $\S \S 1532(13), 1538(a)(1)(B)$ (2012).

134. Id. § 1536(a)(2).

135. 50 C.F.R. $\$ 402.14(a)$.

136. Id. $\$ 402.14(\mathrm{~g})(4)$.

137. Id. $\S 402.14(\mathrm{i})$.

138. 16 U.S.C. $\S 1536(b)(3)(A)$ (2012).

139. Id. § 1539 . 
tains to all private actors, via its broad take prohibitions, and it has no inherent exemptions. ${ }^{140}$ Section 7 directly addresses only federal actions, but indirectly constrains private actions through its inclusion of actions authorized or funded by federal agencies. ${ }^{141}$ Permits to fill wetlands, for example, are generally granted by the U.S. Army Corps of Engineers under Section 404 of the CWA, ${ }^{142}$ and these permitting decisions all require compliance with Section 7 of the ESA. ${ }^{143}$ Sections 4, 7, and 9 provide the majority of the ESA's restrictions, and the administrative evolutions discussed in detail below build on and reshape that body of law.

\section{The Case for the ESA as a Study in Administrative Evolution}

The ESA provides an ideal study system for documenting the growing importance of administrative agencies in facilitating the evolution of the law due to the Act's statutory stagnancy, its heavy reliance on science, the power granted to the Services by the Act, and its controversial nature. An unchanging Act, a setting rife with selective pressures, and administrative agencies empowered to change the way the Act work should provide fertile ground for administrative evolution of the law.

First, the law itself has remained largely unchanged since the early 1980s, more than thirty-five years ago. ${ }^{144}$ Most of the major provisions of the Act were established with its passage in 1973, although amendments in $1978^{145}$ and $1982^{146}$ made significant alterations. Because the ESA is largely locked into its current statutory form, ${ }^{147}$ the textual basis of the law has not undergone significant evolution for some time. This means that any significant changes to the law itself must come either through the courts or administrative evolution of the law. With courts largely avoiding the policy debates around the ESA, the Services provide the only remaining outlet for evolution of the Act.

Second, during this thirty-five-year period, scientific understanding of endangered species has undergone a revolution. ${ }^{148}$ In the field of genetics alone, scientific progress has been nothing short of miraculous. In the

140. Id. § 1538(a)(1).

141. Id. $\$ 1536(\mathrm{a})$.

142. 33 U.S.C. $\$ 1344$ (2012).

143. 16 U.S.C. $\S 1536(\mathrm{e})(3)(\mathrm{B})(2012)$.

144. Doremus, supra note 6, at 182 (noting that "the key features of the [ESA] have proved surprisingly politically resilient.").

145. Endangered Species Act Amendments of 1978, Pub. L. No. 95-632, 92 Stat. 3751 (adding the "God Squad," consultation, incidental take, and critical habitat provisions).

146. Endangered Species Act Amendments of 1982, Pub. L. No. 97-304, 96 Stat. 1411 (adding protections for plants, experimental populations, and best available science requirements, among other changes).

147. See History of the Endangered Species Act, BAllotPedia, https://ballotpedia.org/ History_of_the_Endangered_Species_Act [http://perma.cc/VA33-P37P] (last visited Nov. $5,2018)$.

148. Michael O'Connell, Response to: "Six Biological Reasons Why the Endangered Species Act Doesn't Work and What to Do About It," 6 Conservation Biology 140, 140 (1992). 
1960s, scientists were determining which three-nucleotide codons in a nucleic acid sequence specified which single amino acid. ${ }^{149}$ By 1999, researchers had decoded the first human chromosome. ${ }^{150}$ And by 2011, of relevance to the Act, researchers published a map of the rainbow trout genome. ${ }^{151}$ These genetic advances gave managers huge amounts of information about the species they managed. ${ }^{152}$ Two reputable new journals dedicated to the use of genetic information in conservation decisions, Molecular Ecology and Conservation Genetics, began in the late 1990s and early 2000s "serv[ing] as evidence of the burgeoning discipline." 153 These scientific developments are particularly meaningful because the Act values science so highly. The ESA requires myriad decisions under the Act be based on the best available science. ${ }^{154}$ This makes the implementation of the Act hinge on the current state of science and so these scientific developments have led to many legal challenges and significant changes in the Act's implementation. Because science has progressed so rapidly since passage of the Act, the Act had to evolve to capitalize on the new science. The Act is set up as a perfect test case for administrative evolution.

Third, courts rely on the Act's wildly ambitious language to grant the Services broad latitude in implementing it, ${ }^{155}$ which encourages the Services to use their power to develop the Act. The Act seeks "to provide a means whereby the ecosystems upon which endangered species and threatened species depend may be conserved, to provide a program for the conservation of such endangered species and threatened species, and to" 156 implement relevant international treaties and conventions. ${ }^{157}$ The Act requires that "all Federal departments and agencies shall seek to conserve endangered species and threatened species and shall utilize their

149. The History of DNA Timeline, DNA WORLDwIDE, https://www.dna-worldwide .com/resource/160/history-dna-timeline [http://perma.cc/4RVA-29GA] (last visited Nov. 5, 2018).

150. Id.

151. Yniv Palti et al., A First Generation Integrated Map of the Rainbow Trout Genome, 10 BMC GenOMICS 462, 462 (2009), https://bmcgenomics.biomedcentral.com/track/pdf/ 10.1186/1471-2164-12-180 [http://perma.cc/M49D-ZVFF].

152. See Doremus, supra note 6 , at 176 , for a detailed discussion of the changes in science and their impacts on the ESA.

153. Sylvia M. Fallon, Genetic Data and the Listing of Species Under the U.S. Endangered Species Act, 21 Conservation Biology 1186, 1187 (2007).

154. The Act requires listing decisions, 16 U.S.C. $§ 1533(b)(1)(A)$ (2012); critical habitat decisions, id. §1533(b)(2); and interagency consultations, id. § 1536(a)(2), must be made based on the best scientific data available. International treaty determinations, $i d$. $\S 1537 \mathrm{a}(\mathrm{c})(2)$, and experimental population determinations, id. $\S 1539(\mathrm{j})(2)(\mathrm{B})$, must be made based on the best available information.

155. Babbitt v. Sweet Home Chapter of Cmtys. for a Great Or., 515 U.S. 687, 703-04 (1995) ("The latitude the ESA gives the Secretary in enforcing the statute, together with the degree of regulatory expertise necessary to its enforcement, establishes that we owe some degree of deference to the Secretary's reasonable interpretation" of the statutory scheme.).

156. 16 U.S.C. $§ 1531$ (b) (2012).

157. Id. 
authorities in furtherance of the purposes of [the Act]." ${ }^{158}$ In essence, the ESA dedicates the significant resources of the administrative state to protecting biodiversity. This kind of lofty language would be easy to wave off, but for the case law giving life to the Act's overarching value system. The Supreme Court set the tone for interpreting the ESA in the landmark Tennessee Valley Authority v. Hill. ${ }^{159}$ There, the Court held that the Act "admits of no exception,"160 "that Congress intended endangered species to be afforded the highest of priorities," 161 and finally that "Congress has spoken in the plainest of words, making it abundantly clear that the balance has been struck in favor of affording endangered species the highest of priorities."162 From the legislative history, the Court noted an "overriding need to devote whatever effort and resources were necessary to avoid further diminution of national and worldwide wildlife resources." 163 Tennessee Valley Authority's broad and aggressive reading of the ESA continues to give the Services significant flexibility to achieve its aims.

Fourth and finally, the Services face intense and opposing public pressure to both aggressively protect species and to avoid economic harm. Michael Bean characterized the two primary forces at play:

The environmental camp ... has argued that the existing law must be strengthened, that it is not accomplishing its vitally important goal of conserving rare species as effectively as it must if it is to stave off a flood of extinctions. The other camp has argued that the existing law is unduly onerous for those whose activities it regulates, and must be made less so. ${ }^{164}$

The Act is "a flash point of contention between defenders of nature and advocates of economic progress." 165 These conflicts make the Act a target, both legislatively and during its implementation.

"ESA-related legislation, passed or proposed, often sparks debates among landowner organizations, environmental groups, and academicians." 166 A recent report on legislative effort to weaken the Act identified "at least 303 direct attacks on the Act since 1996, with the majority of

158. Id. $\S 1531(\mathrm{c})(1)$.

159. Tenn. Valley Auth. v. Hill, 437 U.S. 153, 171-72 (1978).

160. Id. at 173 .

161. Id. at 174 .

162. Id. at 194 ("The plain intent of Congress in enacting this statute was to halt and reverse the trend toward species extinction, whatever the cost. This is reflected ... in literally every section of the statute.").

163. Id. at 177 (quoting George Cameron Coggins, Conserving Wildlife Resources: An Overview of the Endangered Species Act of 1973, 51 N.D. L. REv. 315, 321 (1975)) (emphasis added by the Court).

164. Endangered Species Recovery Act: Hearing on S. 1180 Before the S. Comm. on Env't \& Pub. Works, 105th Cong. 187 (1998) (statement of Michael J. Bean).

165. Brad Knickerbocker, Controversy Erupts over Endangered Species Act, CHRISTIAN SCI. Monitor (July 25, 2007), https://www.csmonitor.com/2007/0725/p02s01-uspo.html [http://perma.cc/5BZR-ER7G].

166. Sayeed R. Mehmood \& Daowei Zhang, A Roll Call Analysis of the Endangered Species Act Amendments, 83 Am. J. Agric. Econ. 501, 501 (2001). 
attacks occurring within the past five years. ... [t]he 114th Congress dramatically increased its efforts to take away protections for species, and set a record-breaking 135 attacks before its departure on December 9, 2016." 167 As of November 2017, in the 115th Congress, "policymakers have introduced 59 legislative measures that are intended to undermine the ESA." 168 Not all of the efforts to amend the Act are one sided, ${ }^{169}$ but efforts to weaken the Act dominate the last decade of legislative activity. ${ }^{170}$

Beyond the legislative agenda, implementation of the Act is particularly controversial when it affects human activities and resources. A study analyzing funding patterns for recovery spending found that congressional earmarking of funds, litigation patterns, lobbying of congressional representatives, and institutional patterns all affect agency spending and "undermine the clear mandate of the ESA and the original intention of Congress." 171 Political pressures can dramatically alter administration of ESA mandates. ${ }^{172}$ FWS Employees report political pressure affecting listing and habitat protection decisions, with a majority of surveyed employees stating "they knew of cases where Interior Department political appointees had interfered with scientific reports and decisions." 173

In spite of these pressures, polling suggests continuing and crosscutting support for the ESA. In one 2015 poll, $90 \%$ of registered voters strongly or somewhat supported the Act, with only 7\% opposed to the Act. ${ }^{174}$ A 2017 poll found $70 \%$ of voters opposed removing protections from listed species, compared to only $22 \%$ who support the idea. ${ }^{175}$ A 2016 poll found $63 \%$ of voters agreed that saving at-risk wildlife from extinction was a "[v]ery important goal for [the] federal government," and another $18 \%$ agreed that it was a "fairly important goal." 176 This support is long-

167. Politics of Extinction, CTr. FOR BIOlogical Diversity, http://www.biological diversity.org/campaigns/esa_attacks/table.html [http://perma.cc/6K9L-NZFD] (last updated Dec. 20, 2017).

168. Jim Lyons, Under Threat: The Endangered Species Act and the Plants and Wildlife it Protects, Ctr. For Am. Progress (Nov. 28, 2017), https://www.americanprogress.org/ issues/green/reports/2017/11/28/443265/under-threat/ [http://perma.cc/5QY4-27HQ].

169. Gardner M. Brown \& Jason F. Shogren, Economics of the Endangered Species Act, 12 J. Econ. Persp. 3,4 (1998) (noting the introduction of bills both strengthening and weakening provisions of the Act).

170. See Politics of Extinction, supra note 167.

171. O'Connell, supra note 148, at 141.

172. Reed D. Benson, So Much Conflict, Yet So Much in Common: Considering the Similarities Between Western Water Law and the Endangered Species Act, 44 NAT. RESOURCES J. 29, 30-32 (2004).

173. Knickerbocker, supra note 165.

174. Ben Tulchin et al., Poll Finds Overwhelming, Broad-Based Support for the Endangered Species Act Among Voters Nationwide 1, 2 (2015), https://earthjustice.org/sites/de fault/files/files/PollingMemoNationalESASurvey.pdf [http://perma.cc/X9R8-TZFK].

175. New Polling Data Underscores Public Support for Endangered Species Protections, WiLdLIFE News (Jan. 18, 2017), http://www.thewildlifenews.com/2017/01/18/new-pollingdata-underscores-public-support-for-endangered-species-protections/ [http://perma.cc/ 77DL-5PZW].

176. Hart Research Assocs., Ctr. For Am. Progress, Public Opinion on Energy, the Environment, and Climate 7 (2016), https://cdn.americanprogress.org/content/uploads/ 
standing; a 1997 poll found "[o]n a scale from 0-100, respondents rated the importance of conserving species at 76.5, similar to the importance of property rights (76.3) and economic growth (75.4)." ${ }^{177}$ These opposing and tremendous pressures within the debate encourage the Services to create innovative solutions to endangered species problems and lead to evolution in species protection.

These four characteristics encourage continued evolutionary development of the Act. To summarize, first, the Act itself is a super statute, largely resistant to change for the last thirty-five years. Second, conservation science has undergone an unprecedented revolution, but the Act has not followed suit. Third, courts have also read the Act to allow significant agency discretion. Fourth, the Act faces intense political pressure from all sides. If law evolves when faced with selective pressures, but the law cannot evolve through changes in the text of the Act or through court decisions, this creates a demand for legal evolution that must be met through administrative evolution of the law. Section III explores the evolution of the ESA through administrative actions in three case studies.

\section{ADMINISTRATIVE EVOLUTION OF THE ENDANGERED SPECIES ACT}

The first case study demonstrates administrative evolution of the definition of a listable species in response to selective pressure from changing science. The second demonstrates administrative evolution in the treatment of private land in response to selective pressure from an abrupt shift in the political climate and the need to improve conservation on that land. The third and final case study demonstrates administrative evolution of species reintroductions in response to selective pressure from the local opponents of the reintroductions. Taken together, these three case studies provide a convincing picture of the administrative evolution of the ESA.

\section{A. Evolution of the Species Definition}

Before the ESA can protect a species, the species must first be listed under the Act. ${ }^{178}$ Listable species include "subspecies of fish or wildlife or plants, and any distinct population segment of any species of vertebrate fish or wildlife which interbreeds when mature." 179 Although taxonomists offer definitions of species and subspecies, ${ }^{180}$ the term "distinct population segment" (DPS) lacks a counterpart in science; hashing out its

2017/01/18040010/E-12075-CAP-Energy-Enviro-Climate-Voters-FINAL.pdf [http://perma .cc/54TL-WE32].

177. Brian Czech \& Paul R. Krausman, Public Opinion on Species and Endangered Species Conservation, 14 Endangered Species Update 7, 9 (1997).

178. 16 U.S.C. $\S 1533(\mathrm{~b})(1)(\mathrm{A})(2012)$.

179. Id. § 1532(16).

180. But see Doremus, supra note 6, at 186-87 ("Subspecies do not have the fundamental biological significance of species.... [T] he subspecies concept is gradually falling out of favour.") (citations and quotation marks omitted). 
definition has created a long history of argument and interpretation. ${ }^{181}$ The breadth of the DPS definition can determine whether a given population will be protected at all. ${ }^{182}$ The DPS term is a cornerstone of the Act's attempt to protect genetic diversity within a species, and long-term species conservation requires maintenance of this intraspecific diversity. ${ }^{183}$ This case study tracks the changing scientific understanding of what constitutes a population worthy of protection and charts the evolution of the administrative definition of a species in light of those changes in the underlying science.

\section{Statutory Definition of Species}

Congress added the DPS language to the Act in 1978,184 and in 1979 the Government Accountability Office (GAO) issued a report criticizing the species definition as too broad. ${ }^{185}$ Congress rejected GAO's call to change the definition, but the Senate Committee on Environment and Public Works admonished the Services to use the DPS concept "sparingly and only when the biological evidence indicates that such action is warranted." 186 The Services repeatedly cite this language as a reason to interpret the definition narrowly. ${ }^{187}$ This history suggests "Congress intended to protect at least distinct forms, genetic resources, and domestic populations," 188 but "[t]he task of defining and listing endangered and threatened species requires an expertise and attention to detail that exceeds the normal province of Congress." 189

Scientifically, this initial legislation is significant because it assumed a static view of nature and a view that evolution did not matter in the short term, reflecting the dominant scientific paradigms of the era. ${ }^{190}$ Popula-

181. See Policy Regarding the Recognition of Distinct Vertebrate Population Segments Under the Endangered Species Act, 61 Fed. Reg. 4,722, 4,722-25 (Feb. 7, 1996) [hereinafter Joint Policy].

182. Doremus, supra note 6, at 188.

183. David H. Reed \& Richard Frankham, Correlation Between Fitness and Genetic Diversity, 17 Conservation Biology 230, 234 (2003); R. Frankham, Conservation Genetics, 29 Ann. Rev. Genetics 305, 306 (1995).

184. 16 U.S.C. $\$ 1532(16)$ (2012). The statutory definition of species took its current form in 1982 when Congress mandated that definitional decisions being made turn "solely on the basis of the best scientific and commercial data available." Endangered Species Act Amendments of 1982, Pub. L. No. 97-304, 96 Stat. 1411.

185. U.S. Gov't Accountability Office, CED-79-65, Endangered Species-A Controversial Issue Needing Resolution 52 (1979).

186. S. Rep. No. 96-151, at 7 (1979), reprinted in Congressional Research Service, A Legislative History of the Endangered Species Act of 1973, at 1397 (1980).

187. Joint Policy, 61 Fed. Reg. 4,722, 4,722 (Feb. 7, 1996). This deference to a suggestion from a single Senate committee is unwarranted. See William N. Eskridge, Interpreting Legislative Inaction, 87 MicH. L. REV. 67, 69-70 (1988).

188. Holly Doremus, Listing Decisions Under the Endangered Species Act: Why Better Science Isn't Always Better Policy, 75 WAsh. U. L.Q. 1029, 1095 (1997).

189. Babbitt v. Sweet Home Chapter of Cmtys. for a Great Or., 515 U.S. 687, 708 (1995).

190. Doremus, supra note 6, at 202 (noting that "the ESA frames the taxonomy issue in a static way. That was very much the scientific perspective of the time. Biologists ... did not think [evolution] occurred at time scales relevant to human decision-making."). 
tion genetics was largely nonexistent in the 1970s, and without a broader population genetics context, taxonomy inevitably focused on morphological differences in the here and now, not the historical or future evolutionary trajectory of a population. ${ }^{191}$

\section{Early DPS Listings}

During the first decade after the DPS amendment, the Services made little effort to list DPSs and offered little justification when they did so. ${ }^{192}$ The decisions in that era lacked any explicit discussion of what made these populations DPSs, and none of the listings even used the term DPS. This relaxed setting changed in 1989, when the Sierra Club Legal Defense Fund filed the first DPS-based law suit, a challenge to FWS's failure to consider whether the silver rice rat qualified as a DPS. ${ }^{193}$ In response, FWS undertook review of the silver rice rat as a distinct population segment ${ }^{194}$ and the Services also began rumblings about making a DPS rule, but failed to do so in the near term. ${ }^{195}$ The late 1980s also marked an uptick in conservationists' focus on populations, a shift from a near-exclusive focus on species or ecosystem level concerns to a focus largely on protecting population-level diversity. ${ }^{196}$

In response to the lawsuit and the growing scientific pressure, DPS listings began a steady climb. Although the numbers are a little sketchy, in 1988, petitioners submitted four listings petitions, including one for a DPS. ${ }^{197}$ By 1990, this grew to 31 petitions and five for DPS, and by 1992, thirty-six and ten. ${ }^{198}$ Petitions increasingly sought both listing of a full

191. See id. at 201; see also Gerald R. Smith \& Ralph F. Stearley, The Classification and Scientific Names of Rainbow and Cutthroat Trouts, 14 Fisheries 4, 4 (1989) (providing evidence of this taxonomic approach, coupled with a historical view of the development molecular ecology approaches to taxonomy).

192. See U.S. Fish \& Wildlife Serv., FWS \& NOAA-Fisheries Species Listed as Distinct Population Segments (DPS), Envtl. Conservation Online Sys., https://ecos.fws.gov/ ecp/report/table/species-listed-as-distinct-population-segments.html [http://perma.cc/ ANL2-EMZX] (last visited Nov. 3, 2018) (FWS listing only ten domestic populations of otherwise unlisted species listed as DPSs by 1989, with only cursory justifications); ENDANgered Species: A Controversial Issue Needing Resolution, supra note 185, at 105.

193. Proposed Endangered Status for the Lower Keys Population of the Rice Rat (Silver Rice Rat), 55 Fed. Reg. 43,002, 43,006 (Oct. 25, 1990).

194. Id. FWS ultimately listed the rat as a DPS due to its isolation and unique silver fur and long nasal bones. Id.

195. Maine v. Norton, 257 F. Supp. 2d 357, 379 (D. Me. 2003) (noting a public meeting on DPS definitions); see Proposed Endangered Status for the Lower Keys Population of the Rice Rat (Silver Rice Rat), Fed. Reg. at 43,004; Definition of Vertebrate Populations, 55 Fed. Reg. 44,592, 44,592 (Oct. 29, 1990) (announcing that a notice of proposed rulemaking would be forthcoming).

196. Robin S. Waples, Distinct Population Segments, in The Endangered Species Act at Thirty: Volume 2, Conserving Biodiversity in Human-Dominated LandSCAPES 127, 127 (J. Michael Scott et al. eds., 2006).

197. U.S. Fish \& Wildlife Serv., Endangered Species Act Petitions Received by Fish and Wildlife Service, Envtl. Conservation Online Sys., https://ecos.fws.gov/ecp/report/ta ble/petitions-received.html (last visited Jan. 8, 2019).

198. See id. 
species and, in the alternative, listing of separate DPSs of that species. ${ }^{199}$ As a result, by 1993 the Services had begun evaluating both whole species and potential DPSs within that species when addressing any listing petition. ${ }^{200}$

In an evolutionary sense, the Services moved from a selective environment where they evaluated only handful of potential DPSs on relatively uncontroversial cases to a selective environment where virtually every petition presented DPS issues and the threat of litigation hung as a constant presence in the background. ${ }^{201}$ When faced with increased pressure during the 1990s, the Services evolved the DPS law through rulemaking. They moved from their relaxed early efforts, to a piecemeal approach where some submissions were considered for a DPS listing, to an approach where every petitioned species received consideration both as a full species and as a separate DPS. ${ }^{202}$

\section{Rulemaking to Define a DPS}

NMFS's need for a DPS policy quickly became acute, as the agency faced several listing petitions for populations of pacific salmon in the wake of the sharp coast-wide decline in salmon populations beginning in 1990. ${ }^{203}$ In 1991, NMFS published a "Definition of 'species' under the Endangered Species Act: Application to Pacific Salmon," (ESU Policy) which created NMFS's Evolutionarily Significant Unit (ESU) concept for use with pacific salmonids. ${ }^{204}$ This ESU Policy, generally treated as a rulemaking, marked the next step in an administrative evolution of the species definition under the Act, in that it defined a DPS as an ESU. ${ }^{205}$ NMFS's 1991 policy established two criteria for listing a pacific salmonid DPS: "(1) It must be substantially reproductively isolated from other nonspecific population units; and (2) it must represent an important component in the evolutionary legacy of the species."206

199. See, e.g., Endangered and Threatened Wildlife and Plants; 90-Day Finding and Commencement of Status Review for a Petition to List the Bull Trout, 58 Fed. Reg. 28,849, 28,849 (May 17, 1993) ("T] he petitioners also requested the emergency listing of bull trout populations in a number of select 'aquatic ecosystems.'”).

200. See, e.g., id. at 28,852 ("As a part of this review, the Service will evaluate the status of distinct population segments and determine whether listing is warranted for either the species rangewide or certain distinct population segments.").

201. See Proposed Endangered Status for the Lower Keys Population of the Rice Rat (Silver Rice Rat), 55 Fed. Reg. 43,002, 43,004 (Oct. 25, 1990).

202. See Endangered and Threatened Wildlife and Plants; 90-Day Findings and Commencement of Status Review for a Petition to List the Bull Trout, 58 Fed. Reg. at 28,849, 28,852 .

203. Donald J. Noakes et al., On the Decline of Pacific Salmon and Speculative Links to Salmon Farming in British Columbia, 183 Aquaculture 363, 363-64 (2000).

204. See generally Policy on Applying the Definition of Species Under the Endangered Species Act to Pacific Salmon (hereinafter "ESU Policy"), 56 Fed. Reg. 58,612 (Nov. 20, 1991).

205. The policy, authored by Robin Waples, built on a 1981 paper, input from an ESA technical Committee, and a public workshop. Robin S. Waples, Pacific Salmon, Oncorhynchus spp., and the Definition of "Species" Under the Endangered Species Act, 53 MARINE FISHERIES REV. 11, 12 (1991).

206. ESU Policy, 56 Fed. Reg. at 58,612. 
NMFS's definition is remarkable in two ways. First, it focuses almost entirely on genetics as a driver for population listing, ${ }^{207}$ setting a pattern for salmonid listing decisions over the next several years. ${ }^{208}$ Second, the 1991 rulemaking expressly followed the static view of evolution encapsulated in the Act itself, ${ }^{209}$ focusing on protection of a species' "evolutionary legacy," that is, "the genetic variability [from] past evolutionary events." 210 In short, the "policy presents its purpose in a [] static manner."211

As might be expected, NMFS's ESU Policy and their subsequent rulemakings sparked increased academic interest in the ESA population question. ${ }^{212}$ Congress got in on the Act as well, requesting a National Academy of Sciences (NAS) study of the definition of the term species under the Act. ${ }^{213}$ In 1995, the NAS responded with several critiques. ${ }^{214}$ Reacting to the NAS study, increasing DPS-based petitions and litigation, ${ }^{215}$ and the burgeoning scientific literature on listable populations, the Services finally developed a joint DPS policy (Joint Policy) in 1996.216 The Joint Policy based its DPS definition on two factors: one, the discreteness of the population segment in relation to the remainder of its

207. In response to several comments emphasizing broader values, like "the importance of preserving biodiversity and the aesthetic, ecological, recreational, and scientific value," $i d$. at 58,613 (internal quotation marks omitted), the agency responded that "[a]ttempting to preserve populations for their aesthetic, scientific, or recreational value without regard to the underlying genetic basis for diversity focuses on attributes that are not directly related to long-term survival of the species," $i d$. at 58,614, and is thus not allowed under its interpretation of the ESA. $I d$.

208. See, e.g., Threatened Status for Snake River Spring/Summer Chinook Salmon, Threatened Status for Snake River Fall Chinook Salmon, 57 Fed. Reg. 14,653, 14,654 (Apr. 22,1992 ) (relying heavily on absence of genetic information to combine the spring and summer runs of Chinook salmon into one DPS, and similarly using genetic data to justify listing the fall run fish as a separate DPS); Mid-Columbia River Summer Chinook Salmon, 59 Fed. Reg. 48,855, 48,858-59 (Sept. 23, 1994) (determining that a lack of evidence of genetic isolation precluded listing of the mid-Columbia River summer Chinook as a DPS).

209. NMFS rejected protection for newly isolated populations, arguing that "considering recently isolated stocks to be ESUs simply on the basis of their isolation is not appropriate," but a comprehensive view of evolution, one that does not take a static view of the process would require protection of these populations. ESU Policy, 56 Fed. Reg. at 58,616.

210. Id.

211. Doremus, supra note 6, at 199.

212. See, e.g., Craig Moritz, Defining 'Evolutionarily Significant Units' for Conservation, 9 Trends Ecol. Evol. 373, 373 (1994); Kevin D. Hill, The Endangered Species Act: What Do We Mean by Species?, 20 B.C. Envtl. Aff. L. Rev. 239, 239-40 (1993); David S. Wilcove et al., What Exactly Is an Endangered Species? An Analysis of the U.S. Endangered Species List: 1985-1991, 7 Conservation Biology 87, 88 (1993).

213. Nat'l Research Council, Science and the Endangered Species Act 3 (1995).

214. Id. at 3-4.

215. See, e.g., Sw. Ctr. for Biological Diversity v. Babbitt, 926 F. Supp. 920, 926 (D. Ariz. 1996) (noting that there was "no clear and consistent [DPS] policy to which this Court could defer," and invalidating a FWS decision to deny listing to a population of northern goshawk based on FWS's determination that the population did not constitute a DPS); U.S. Fish \& Wildlife Serv., supra note 197. Prosecution of the case would have put the Services on notice of the need for a final DPS policy.

216. Joint Policy, 61 Fed. Reg. 4,722, 4,722 (Feb. 7, 1996). The draft policy came out in December 1994. Id. 
species; and two, the significance of the population segment to its species. $^{217}$ The policy largely tracked the ESU Policy for pacific salmonids, ${ }^{218}$ although the Joint Policy placed much less emphasis on genetic isolation, ${ }^{219}$ instead explicitly recognizing a larger role for "physical, physiological, ecological, or behavioral factors." 220 This approach also leaves a little more room for a non-static view of nature, although the policy does not provide explicit guidance for newly isolated populations. The Joint Policy marked the next evolutionary step for the Services, as it was clearly iterative and constrained by the prior ESU Policy. ${ }^{221}$ The Joint Policy reflects the selective pressures of the increased congressional oversight and negative feedback from the NAS study.

Although the continued application of the ESU Policy and the application of the new Joint Policy produced significant debate among commentators, ${ }^{222}$ little of this criticism moved beyond the academic literature. The Services' ESU and Joint Policy faced only light selective pressure until a series of court cases beginning in 2001.223 Many of these cases focused on the application of the ESU concept to pacific salmonids, and administrative infighting combined with this series of judicial decisions to create strong selective pressures on NMFS, resulting in a rapid evolution of their approach to listing steelhead DPSs.

\section{Steelhead/Rainbow Trout DPS Controversy}

Steelhead are the ocean-going form of rainbow trout, Onchorhynchus mykiss. Like salmon, steelhead are born in fresh water and eventually migrate out to the ocean to mature. ${ }^{224}$ After a variable number of years, mature steelhead migrate upstream to their natal streams to breed.225

217. Id.

218. ESU Policy, 56 Fed. Reg. 58,612, 58,612 (Nov. 20, 1991).

219. Compare the discreteness factor in the Joint Policy with the substantial reproductive isolation factors of NMFS's ESU Policy, and the significance factor in the Joint Policy with important component in the evolutionary legacy factor of NMFS's ESU Policy.

220. Joint Policy, 61 Fed. Reg. at 4,725.

221. The Services noted that "NMFS policy for salmonids is consistent with the [Joint Policy], although the salmonid policy is formulated specifically to address the biology of this group," id. at 4,723, and called the ESU Policy "a detailed extension of this joint policy." Id. at 4,722 .

222. Consider, for example, the long running peer reviewed conversation between NMFS scientist Robin Waples and two other prominent conservation biologists. See Tanya A. Gulesserian, The Departments of Commerce and Interior: Bifurcating an Evolutionary Significant Unit Under the Endangered Species Act, 23 VT. L. REv. 605, 633-34 (1999) (collecting citations).

223. See, e.g., Trout Unlimited v. Lohn, 559 F.3d 946, 956 (9th Cir. 2009); Nw. Ecosys. All. v. U.S. Fish \& Wildlife Serv., 475 F.3d 1136, 1143-45 (9th Cir. 2007); Nat'l Ass'n of Homebuilders v. Norton, 340 F.3d 835, 838 (9th Cir. 2003); Defenders of Wildlife v. Norton, 258 F.3d 1136, 1144-45 (9th Cir. 2001); Alsea Valley All. v. Evans, 161 F. Supp. 2d 1154, 1163 (D. Or. 2001); see also Katherine M. Hausrath, Note, The Designation of "Distinct Population Segments" Under the Endangered Species Act in Light of National Association of Homebuilders $v$. Norton, 80 ChI.-Kent L. REv. 449, 452-54 (2005).

224. Thomas P. Quinn, The Behavior and Ecology of Pacific Salmon and Trout 68 (Univ. of Washington Press, 2005).

225. Id. at 69. 
Two aspects of steelhead make them a particularly strong candidate for observing administratively-driven legal evolution. First, due to their prevalence around water infrastructure on the west coast, NMFS faces serious political and legal pressure concerning listing and management of the steelhead. ${ }^{226}$ Second, the science around steelhead has been particularly active. ${ }^{227}$ Perhaps the most significant scientific development regarding steelhead listings has been the elucidation of the steelhead's relationship to resident rainbow trout. Historically, commentators believed that steelhead and trout in the same stream did not interbreed.228 By 1996, NMFS began to realize that some interbreeding or crossover between the populations might occur. ${ }^{229}$ Given the way that the ESU Policy defined listable populations (i.e. emphasis on substantial reproductive isolation demonstrated by a lack of gene flow with another population), ${ }^{230}$ this new knowledge, coupled with the high stakes of water politics on the west coast, was bound to spark rapid evolution in the law.

Prior to 2001, NMFS followed its established ESU Policy for listing the steelhead. ${ }^{231}$ In response to several steelhead listing petitions in the mid1990s, NMFS sought to delineate fifteen steelhead ESUs. ${ }^{232}$ In 1996, NMFS found that genetic information required it to define ESUs that included steelhead and rainbow trout. ${ }^{233}$ But FWS, which has jurisdiction over freshwater fish, stymied NMFS's efforts to include resident rainbow trout in the steelhead listing. ${ }^{234}$ FWS determined that "only the anadromous forms of $O$. mykiss should be included in the listed steelhead ESUs at this time." 235 In response, NMFS determined the resident trout were still part of the ESU, but listed only the anadromous portion of the ESU, in effect parsing the ESU into two parts for listing purposes. ${ }^{236} \mathrm{~A}$ few

226. See, e.g., Peter B. Moyle et al., State of the Salmonids (2017) (identifying dams as the single biggest threat to steelhead existence in California).

227. See, e.g., Eggy J. Busby et Al., U.S. Dep't of Commer., NOAA Tech. Memo., NMFS-NWFSC-27, Status Review of West Coast Steelhead from Washington, IdAho, Oregon, ANd California (1996).

228. See, e.g., Ferris Neave, Racial Characteristics and Migratory Habits in Salmo Gairdneri, 6 J. Fisheries Res. BoARd CAN. 245, 251 (1944); see also Christian E. Zimmerman \& Gordon H. Reeves, Population Structure of Sympatric Anadromous and Nonanadromous Oncorhynchus Mykiss: Evidence from Spawning Surveys and Otolith Microchemistry, 57 CAn. J. Fisheries \& Aquatic SCI. 2152, 2153 (2000) ("The relationship of migratory and resident forms of rainbow trout has long confused biologists.").

229. BUSBY ET AL., supra note 227, at 11, 58.

230. ESU Policy, 56 Fed. Reg. 58,612, 58,612 (Nov. 20, 1991).

231. Gulesserian, supra note 222, at 606-07 (criticizing as unlawful NMFS's decision to list steelhead separately from rainbow trout).

232. BusBy ET AL., supra note 227, at 55; Endangered and Threatened Species: Listing of Several Evolutionary Significant Units (ESUs) of West Coast Steelhead, 62 Fed. Reg. 43,937, 43,941 (Aug. 18, 1997).

233. Proposed Endangered Status for Five ESUs of Steelhead and Proposed Threatened Status for Five ESUs of Steelhead in Washington, Oregon, Idaho, and California, 61 Fed. Reg. 41,541, 41,543 (Aug. 9, 1996).

234. Letter from Michael J. Spear, Reg'l Dir. of the Fish and Wildlife Serv., to William W. Stelle, Jr., Northwest Reg'l Adm'r for the Nat'l Marine Fisheries Serv. 2 (July 29, 1997). 235. Id. at 3 .

236. Endangered and Threatened Species: Listing of Several Evolutionary Significant Units (ESUs) of West Coast Steelhead, 62 Fed. Reg. at 43,941. 
years later, in the 2001 Alsea Valley Alliance v. Evans decision, ${ }^{237}$ a district court found that any division for listing purposes below the DPS (and hence ESU) level was "not allowed under the ESA,"238 creating serious problems for NMFS's steelhead listing practices. NMFS agreed to undertake a comprehensive reevaluation of its west coast salmonid listings, including "(1) a public rulemaking process to formulate ESA listing standards for salmon ESUs ... [and] (2) application of these standards to all relevant salmon and steelhead ESUs."239

This legal pressure dovetailed with a transition in the science of evolution and molecular ecology that also applied selective pressure to the ESU approach. As discussed above, prior to the early 2000s, a static view of species and evolution dominated both the scientific community and the legal world. During the formation of the DPS policies, many scientists "thought of evolution as an historical process. ... [A]lthough they knew that evolution was never over, they did not think it occurred at time scales relevant to human decision-making." 240 Most ecologists took the view that contemporary evolution was rare. ${ }^{241}$ This view became increasingly untenable in the early 2000 s, as study after study documented rapid evolutionary changes in populations, often coming within only a few generations. ${ }^{242}$ Notably, NMFS scientists were involved in some of the research documenting contemporary evolution in pacific salmonids, so

NMFS believes available evidence suggests that resident rainbow trout should be included in listed steelhead ESUs in certain cases. Such cases include: (1) Where resident O. mykiss have the opportunity to interbreed with anadromous fish below natural or man-made barriers; or (2) where resident fish of native lineage once had the ability to interbreed with anadromous fish but no longer do because they are currently above human-made barriers, and they are considered essential for recovery of the ESU.

Id. "[T] he FWS, which has ESA authority for resident fish, maintains that behavioral forms can be regarded as separate DPSs ... and that absent evidence suggesting resident rainbow trout need ESA protection, the FWS concludes that only the anadromous forms of each ESU should be listed under the ESA." Id. "At this time, NMFS is listing only anadromous life forms of $O$. mykiss." Id. at 43,951.

237. Alsea Valley All. v. Evans, 161 F. Supp. 2d 1154, 1163 (D. Or. 2001).

238. Id. at 1162 .

239. Alsea Valley All. v. Dep’t of Commerce, 358 F.3d 1181, 1183 (9th Cir. 2004).

240. Doremus, supra note 6, at 202.

241. Craig A. Stockwell et al., Contemporary Evolution Meets Conservation Biology, 18 Trends Ecol. Evol. 94, 94 (2003).

242. See id.; Philipp W. Messer et al., Can Population Genetics Adapt to Rapid Evolution?, 32 Trends Genetics 408, 408 (2016); Robin S. Waples et al., Evolutionary Responses by Native Species to Major Anthropogenic Changes to Their Ecosystems: Pacific Salmon in the Columbia River Hydropower System, 17 Molecular Ecology 84, 84 (2008). These three review articles document numerous studies in the early 2000s that found rapid evolution on the time scale of a decade or two. See, e.g., Peter R. Grant \& B. Rosemary Grant, Unpredictable Evolution in a 30-Year Study of Darwin's Finches, 296 SCIENCE 707, 707 (2002) (rapid evolution of beak shape and body size over a thirty-year period in Darwin's finches on the Galápagos islands); Hitoshi Araki et al., Genetic Effects of Captive Breading Causes a Rapid, Cumulative Fitness Decline in the Wild, 318 SCIENCE 100, 100-02 (2007). Genetic effects of captive breeding cause a rapid, cumulative fitness decline in the wild. $I d$. (even one generation of hatchery breeding in salmon led to striking genetic changes and decreased fitness). 
NMFS was certainly aware of the evolving scientific understanding. 243 NMFS sought new guidance on the issue by asking an independent panel of experts headed by Jody Hey (Hey Panel) whether the ESU Policy accounted for contemporary evolution and what NMFS should do with the trout/steelhead question. ${ }^{244}$ The Hey Panel recommended that NMFS shift away from its prior focus on evolutionary legacy when determining whether a population could be listed under the Act and that trout and steelhead be listed together as an ESU. ${ }^{245}$ The panel suggested that NMFS focus on "ecological exchangeability [i.e. the ecological context faced by the population] and the short term evolutionary forces." 246 For an agency required to make decisions based on the best available science, this change was important. NMFS could not continue to ignore contemporary evolution in its determinations of which populations constituted a listable species under the ESA. ${ }^{247}$

In January 2006, NMFS completed its comprehensive status review and listed ten DPSs of steelhead. ${ }^{248}$ The listing process was protracted. ${ }^{249}$ NMFS again initially proposed listing resident trout as part of steelhead ESUs in some cases, but FWS again rebuffed their effort. ${ }^{250}$ Ultimately, NMFS departed from its longstanding use of the ESU Policy in evaluating the proposed steelhead populations. Instead, it applied the Services' broader Joint Policy, which allowed NMFS to list populations of steelhead while excluding the resident fish. While tacitly acknowledging the bureaucratic background, NMFS maintained that the marked separation between the anadromous and resident life-history forms "[based on] physical, physiological, ecological, and behavioral factors" 251 made them discrete, in keeping with the requirements of the Joint Policy. This listing decision was challenged in both federal district $\operatorname{court}^{252}$ and the Ninth Circuit, ${ }^{253}$ and both courts explicitly upheld NMFS's decision to change

243. See e.g., Waples et al., supra note 242. Dr. Waples was the lead author of NMFS's ESU Policy.

244. Jody Hey et al., Considering Life History, Behavioral, \& Ecological Complexity in Defining Conservation Units for Pacific Salmon: An Independent PANel Report, ReQuested by NOAA Fisheries 1 (2005), https://www.researchgate.net/ publication/237209612_Considering_Life_History_Behavioral_and_Ecological_Complexity _in_Defining_Conservation_Units_for_Pacific_Salmon [http://perma.cc/BN6Y-2BEL].

245. Id. at 7 .

246. Id.

247. Doremus, supra note 6, at 223 ("The ESU and DPS Policies ... turn the Services' attention too much to the evolutionary past and too little to the evolutionary future.").

248. Endangered and Threatened Species: Final Listing Determinations for 10 Distinct Population Segments of West Coast Steelhead, 71 Fed. Reg. 834, 834 (Jan. 5, 2006) (to be codified at 50 C.F.R. pts. 223, 224).

249. Id. at 835 (NMFS extended comments twice, closed comments, and then reopened comments, seeking additional comments on its proposed fix to the administrative impasse).

250. Id.

251. Id.

252. Grange v. Nat'l Marine Fisheries Serv., 620 F. Supp. 2d 1111, 1112 (E.D. Cal. 2008).

253. Modesto v. Gutierrez, 619 F.3d 1024, 1026 (9th Cir. 2010). 
its listing criteria. ${ }^{254}$ The Ninth Circuit concluded that

[i]n light of the evolving understanding of the differences between the fish, the desire for a flexible policy, and the depth of consideration that NMFS has given the issue over close to two decades, we conclude that the agency was not arbitrary or capricious in changing its policy in order to protect the steelhead. ${ }^{255}$

The ruling appears to have ended the resident/steelhead dispute, at least for the time being. 256

\section{Evidence for Legal Evolution from Species Definitions}

The development of the species definition, from the early years, through the ESU and the Joint Policy, to the final reversal on treatment of steelhead populations, follows a notably evolutionary trajectory. From an evolutionary perspective, the early years were a period of relaxed selection, that is, a period when sources of selection on a particular trait are weakened or eliminated. ${ }^{257}$ In biological systems, traits facing weak or no selective pressure exhibit wide variation. ${ }^{258}$ When the Services faced little selective pressure on their DPS-related decisions, ${ }^{259}$ their DPS approach varied widely from case to case. This gave the Services significant flexibility to try myriad approaches at little or no cost to the agency, and the early listings show significant evidence of this kind of variation-the Services-based DPS designations on separation of breeding areas, ${ }^{260}$ use of populations in prominent studies, ${ }^{261}$ geographic isolation, ${ }^{262}$ and administrative convenience. ${ }^{263}$ This period of relaxed selection ended with the silver rat lawsuit and the burgeoning interest in populations as units of

254. See e.g., Waples et al., supra note 242; see also ESU Policy, 56 Fed. Reg. 58,612, 58,612 (Nov. 20, 1991).

255. Modesto, 619 F.3d at 1037.

256. While this appears to have resolved the immediate anadromous/resident issue for NMFS, it invites reevaluation of the Services' current classification of other steelhead populations, not evaluated in the rulemaking, which is based entirely on the abandoned ESU Policy.

257. David C. Lahti et al., Relaxed Selection in the Wild, 24 Trends Ecol. Evol. 487, 487 (2009).

258. Id.

259. Until the silver rat case, research uncovers no challenges to a DPS delineation.

260. E.g., Interior Population of Least Tern to be Endangered, 50 Fed. Reg. 21,784, 21,784 (May 28, 1985) (to be codified 50 C.F.R. pt. 17).

261. Listing as Threatened With Critical Habitat for the Beaver Dam Slope Population of the Desert Tortoise in Utah, 45 Fed. Reg. 55,654, 55,660, 55,662 (Aug. 20, 1980) (codified at 50 C.F.R. $\$ 17.11$ (2018)) (relying on the population's "historical preeminence in turtle ecological studies").

262. See, e.g., Determination of Endangered Status for Population of Woodland Caribou Found in Washington, Idaho, \& Southern British Columbia, 48 Fed. Reg. 49,245, 49,245 (Oct. 25, 1983) (codified at 50 C.F.R. \$17.11).

263. See Determination of Endangered and Threatened Status for Piping Plover, 50 Fed. Reg. 50,726, 50,730 (Feb. 11, 1985) (codified at 50 C.F.R. \$17.11) ("The Service's breakdown of the plover's breeding range into the Atlantic coast breeding range, Great Lakes region, and northern Great Plains is not intended to convey the occurrence of subspecies or totally separate genetic populations, but rather to take note of the discontinuous distribution of the species."). 
conservation, and in response the Services moved to a unitary approach, analyzing every submission for potential listing as a DPS (or, in NMFS' case, an ESU). This is variation and then selection down to a small subset of approaches.

The Services made do with the two listing approaches for half a decade, until the selective environment tightened once again, and new science, coupled with the Alsea decision, forced NMFS to change its approach. NMFS considered a range of possibilities, gathered through rulemaking and suggestions from FWS, before selecting the DPS approach to listing steelhead as reflected by the final listing determination. This final listing determination is a strange outcome that clearly results from the constraints of NMFS's prior listing policies and the overall constraints of the ESA itself. It is strange in several ways-particularly because it does not reflect the state of the science on resident and anadromous steelhead populations. ${ }^{264}$ It fails to reflect the reasoned responses from the Hey Panel, which was supposed to guide the relisting effort. ${ }^{265}$ And it belies the Services' longstanding position that the ESU was a specialized application of the DPS policy. ${ }^{266}$

NMFS's listing policy faced serious selective pressures, from both the science (which mandated that resident fish be listed with steelhead), and from litigation and the broader public (which demanded protection for the steelhead portions of the rainbow trout populations, which might be impossible if resident fish were listed with steelhead). ${ }^{267}$ NMFS was constrained in the approaches it could take by its past policies (the ESU Policy and the Services Joint Policy) and by FWS's inherent power to limit NMFS's steelhead listing efforts. In a word, this is inheritance. Ultimately, NMFS tried twice to follow the science and list steelhead and resident rainbow trout in the same ESU, only to have FWS stymie both efforts, and NMFS was forced into a convoluted and perhaps illegal way to separate out the resident fish. This inelegant solution, not an ideal solution from a policy or science perspective, is exactly the kind of local optimum that serves as significant evidence of evolution. ${ }^{268}$ Better solutions exist, but, like the ladybug, NMFS couldn't get there from where it began.

264. For newer data, see C.E. Zimmerman et al., Maternal Origin \& Migratory History of Steelhead \& Rainbow Trout Captured in Rivers of the Central Valley, California, 138 Transactions Am. Fisheries Soc. 280 (2009); see also D.A. Weigel et al., Fluvial Rainbow Trout Contribute to the Colonization of Steelhead (Oncorhynchus Mykiss) in a Small Stream, 97 Environmental Biology of Fishes 1149 (2013); I.I. Courter et al., Resident Rainbow Trout Produce Anadromous Offspring in a Large Interior Watershed, 70 CANADiAn J. Fisheries \& Aquatic Scis. 701 (2013).

265. HEY ET AL., supra note 244, at 7.

266. If it were, surely application of the DPS policy would have resulted in the same outcome for steelhead and resident fish as the ESU Policy had.

267. UC Davis Center for Watershed Resources, Are Central Valley Steelhead Really Threatened?, CAlifornia WATERBlog (Dec. 8, 2013), https://californiawaterblog.com/ 2013/12/08/are-central-valley-steelhead-really-threatened/ [http:// perma.cc/KVJ2-UU62].

268. See Schwartz, supra note 123, at 292-93. 
Although the application of the ESU/Joint Policy to steelhead populations appears settled for now, the broader DPS policy appears likely to face continued evolutionary pressures. In the steelhead rulemaking, NMFS noted that "NMFS and FWS also intend to continue to evaluate application of the statutory term 'distinct population segment' in a process outside the context of a species-specific listing." 269 The policy continues to face court challenges, ${ }^{270}$ critical commentary, ${ }^{271}$ and continued pressure from the scientific community both as criticism of existing practices ${ }^{272}$ and continued development of molecular genetics and evolution. ${ }^{273}$ The evolution of species law will continue.

\section{B. Evolution of the Safe Harbor Program without a Statutory Framework}

The next evolutionary case study focuses on the development of the ESA Safe Harbor program. Essentially, this program encourages private landowners to improve habitat for endangered species on their land by granting them immunity from the ESA's take prohibitions for listed species that utilize the improved habitat. This popular program evolved due to two selective forces: a recognition that successful conservation of many listed species would require habitat on private land, and the significant political pressure on the Act that grew out of the property rights movement.

\section{Political and Scientific Pressure}

In the early 1990s, tensions were running high between landowners and FWS in the Sandhills region of North Carolina. ${ }^{274}$ The area hosted a large population of the endangered red-cockaded woodpeckers (RCWs) essential for the recovery of the species as a whole. But roughly $30 \%$ of Sandhills RCWs lived on private land, and the private land flocks had declined significantly since the 1980 s. $^{275}$ Although the ESA protects occu-

269. Endangered and Threatened Species: Final Listing Determinations for 10 Distinct Population Segments of West Coast Steelhead, 71 Fed. Reg. 834, 834 (Jan. 5, 2006) (to be codified at 50 C.F.R. pts. 223 \& 224).

270. See, e.g., Nat'l Ass'n of Homebuilders v. Norton, 340 F.3d 835, 838 (9th Cir. 2003).

271. See, e.g., Derek O. Teaney, The Insignificant Killer Whale: A Case Study of Inherent Flaws in the Wildlife Services' Distinct Population Segment Policy and a Proposed Solution, 34 ENVTL. L. 647 (2004).

272. See, e.g., Robin S. Waples, \& Oscar Gaggiotti, What is a Population? An Empirical Evaluation of Some Genetic Methods for Identifying Gene Pools \& Their Degree of Connectivity, 15 Molecular Ecology 1419, 1419 (2006); see also Tatjana Rosen, The Endangered Species Act \& the Distinct Population Segment Policy, 18 Ursus 109, 109 (2007).

273. See, e.g., Jon E. Hess, et al., Genetic Basis of Adult Migration Timing in Anadromous Steelhead Discovered Through Multivariate Association Testing, 283 Proc. R. Soc. B. 1,1 (2016) (discussing the apparent genetic determination of run timing in steelhead, and thus implicitly suggesting that steelhead runs may be separately listable under the ESA).

274. Ted Toombs, Safe Harbor: Helping Landowners Help Endangered Species, 27 Rangelands Archives 35, 35 (2005).

275. Availability of an Environmental Assessment and an Application for an Incidental Take Permit to Implement the Red-cockaded Woodpecker "Safe Harbor" Program in the Sandhills Region of North Carolina, 60 Fed. Reg. 10,400, 10,400-01 (Feb. 24, 1995). 
pied habitat and individual RCWs on private land, it does not provide any affirmative private mandate for conservation, and so FWS had to convince local landowners to voluntarily improve the woodpecker habitat on their land. This was not inherently at odds with the landowners' management objectives, ${ }^{276}$ but the landowners intensely feared increased regulation and loss of control if the RCWs took up residence on their lands. Landowners were preemptively cutting their forests to keep RCWs away. One local landowner had a license plate reading "I EAT RCWS."277 It was an uphill battle for FWS.

This microcosm fairly represented the national scene for the ESA in the mid-1990s. The ESA earned its stripes in the nineties. ${ }^{278}$ First, in 1990, the listing of the northern spotted owl reduced the harvest of old growth forest by more than $80 \% .{ }^{279}$ This listing sparked lawsuits, lobbying, ${ }^{280}$ and fierce protests by both environmentalists and the timber industry. ${ }^{281}$ Protestors nailed dead owls to road signs ${ }^{282}$ and President Bush even convened the "God Squad," a rarely used cabinet-level ESA committee that could permit the extinction of a species due to federal actions under some circumstances. ${ }^{283}$ The Clinton Administration finally developed a logging plan that allowed some limited logging to proceed, but the plan did little to reassure timber and private property rights advocates. ${ }^{284}$

Next, in 1993 and again in 1994, the ESA came up for reauthorization. The democratically-controlled House and Senate could not agree on a reauthorization plan and instead funded the Act on a one-year basis. ${ }^{285}$

276. Toombs, supra note 274 , at 35 .

277. Id.

278. See, e.g., John Leshy, The Babbitt Legacy at the Department of Interior: A Preliminary View, 31 ENVTL. L. 199, 213 (2001) ("When Babbitt took office, the ESA's bite was spreading across the nation to the Pacific Northwest, to Texas, to southern California, to the pine forests of the South, and elsewhere, and its congressional support was steadily eroding.").

279. John H. Cushman Jr., Judge Approves Plan for Logging In Forests Where Rare Owls Live, N.Y. TIMEs, Dec. 22, 1994, at A1 (noting approval of a plan that allow timber companies to take "less than one-fifth of the harvest during the 1980's"); see also Seattle Audubon Soc'y v. Evans, 771 F. Supp. 1081, 1088 (W.D. Wash. 1991) aff'd sub nom. Seattle Audubon Soc'y v. Evans, 952 F.2d 297 (9th Cir. 1991).

280. See, e.g., Seattle Audubon Soc'y, 771 F. Supp. at 1084.

281. Don't Blame the Owl, N.Y. Times, Sept. 21, 1992, at A16.

282. See Les Blumenthal, After 20 Years of Protection, Owl Declining But Forests Remain, McClatchy Newspapers (Sept. 5, 2010), http://www.mcclatchydc.com/news/ nation-world/national/article24592138.html [http://perma.cc/4VF7-ZZ9P]; see also Note Hinting At Fire Threat Found With Dead Spotted Owl, Seattle Times (Jan. 16 1991), http:/ /community.seattletimes.nwsource.com/archive/?date=19910116\&slug=1260870 [http://per ma.cc/NA9N-EHX2].

283. Timothy Egan, Politics Reign at Spotted Owl Hearing, N.Y. Times, Jan. 9, 1992, at A14. The God Squad ultimately approved only thirteen of forty-four proposed national forest timber sales (roughly 2,000 acres) and suffered accusations of ex parte contacts with the White House. See Michael A. Bosh, The "God Squad" Proves Mortal: Ex Parte Contacts and the White House After Portland Audubon Society, 51 Wash. \& Lee L. Rev. 1029, 1029-30 (1994).

284. Cushman, supra note 279 , at A1.

285. Nancy K. Kubasek et al., It Takes an Entire Village to Protect an Endangered Species: Individualism, Overlapping Spheres, and the Endangered Species Act, 10 FordHAM ENVTL. L.J. 155, 194 (1999). 
In November 1994, the Republican Revolution swept elections nationwide, riding a wave of anti-government sentiment. ${ }^{286}$ Newt Gingrich lead the charge with his Contract with America, which included a very strong anti-regulatory bent. Just a few months after taking office, congressional Republicans launched an effort to reign in the ESA, ${ }^{287}$ ultimately settling for a one-year listing moratorium. ${ }^{288}$ The congressional effort to amend the Act eventually failed, and the stalemate on the ESA continued, albeit with intensified rhetoric. The ESA remains without a long-term reauthorization.

Then a 1995 Supreme Court decision further fanned the flames. Although the ESA always protected individual listed animals on private land, the Services expanded the reach of the ESA in the 1970s to protect habitat on private land. ${ }^{289}$ In the early 1990 s, the property rights movement gained steam and launched a litigation campaign to strike down the regulation. ${ }^{290}$ The Supreme Court ultimately ruled 6-3 against them ${ }^{291}$ and the decision stoked the fires of the anti-ESA movement. The dissent argued that the ESA "imposes unfairness to the point of financial ruinnot just upon the rich, but upon the simplest farmer who finds his land conscripted to national zoological use," 292 and "industry groups vowed to carry the anti-regulatory fight to Congress." 293

Even as ESA politics grew rockier, conservationists were beginning to clamor for more help for species on private lands. ${ }^{294}$ Conservation scientists found that private lands played a pivotal role in supporting endangered species conservation and would often be required for endangered species recovery. ${ }^{295}$ A 1994 GAO study found that more than $90 \%$ of listed species occurred on private lands, and two-thirds required private land for most of their habitat. ${ }^{296}$ As a New York Times article in 1995 noted, "protecting wildlife without regulating use of private land has been compared by biologists to playing the piano with just the black keys."297

286. John H. Cushion, Congressional Republicans Take Aim at an Extensive List of Environmental Statutes, N.Y. Times, Feb. 22, 1995, at A14.

287. Id.

288. Kubasek et al., supra note 285, at 194.

289. Endangered and Threatened Wildlife and Plants; Final Redefinition of "Harm", 40 Fed. Reg. 44,412, 44,416 (Sept. 26, 1975) (codified at 50 C.F.R. § 17.3 (2018)) (to emphasize that, for the habitat modification to be a take, it must result for actual death or injury of a protected animal).

290. John H. Cushman Jr., The Supreme Court: Endangered Species; Environmentalists Win a Victory, but Action by Congress May Interrupt the Celebration, N.Y. Times, June 30, 1995, at A24.

291. Babbitt v. Sweet Home, 515 U.S. 687, 697 (1995).

292. Id.

293. Cushman, supra note 290, at A24.

294. David S. Wilcove et al., Rebuilding the Ark: Toward a More Effective Endangered Species Act for Private Land (1996).

295. See, e.g., M.J. Bean \& David S. Wilcove, Ending the Impasse, 13 EnVTL. Forum 22, 22-28 (1996); Robert Meltz, Where the Wild Things Are: The Endangered Species Act and Private Property, 24 ENVTL. L. 369, 370 (1994).

296. U.S. Gov't Accountability Office, GAO/RCED-95-16, Endangered Species Act: Information on Species Protection on Nonfederal Lands 4-5 (1994).

297. Cushman, supra note 290, at A24. 
These studies made it clear that endangered species recovery would require more from private landowners, but the Act offered only prohibitions on private actions, not inducements or proactive requirements. Conservationists needed new tools to get the cooperation they wanted from private landowners. The Act offered no such tools.

\section{Safe Harbor Inception}

In 1995, the FWS Southeast Regional Office, in conjunction with the Environmental Defense Fund (EDF) and other organizations and state foresters, ${ }^{298}$ initiated a new program, the Safe Harbor Program, designed to address some of these concerns within the existing ESA framework. ${ }^{299}$ The Program, created by EDF and an ad hoc working group with representatives from FWS' Raleigh and Asheville Field Offices, Fort Bragg, North Carolina Wildlife Resources Commission, North Carolina Natural Heritage Program, North Carolina State University, and the Sandhills Area Land Trust, ${ }^{300}$ began as a modified Habitat Conservation Plan (HCP), a statutory FWS program designed to mitigate take of a listed species.

The Regional Office launched the Safe Harbor Program to address the RCW in the Sandhills of North Carolina, and within ten years the program "enrolled a total of nearly 45,000 acres in Safe Harbor agreements with the local [FWS] office. [Eighty landowners] pledged to protect habitat for any woodpeckers that may already be on their property and to restore or enhance habitat that additional woodpeckers may use." 301 This first Safe Harbor program was "designed to encourage voluntary RCW habitat restoration or enhancement activities by relieving a landowner who enters into a cooperative agreement with the Service from any additional responsibility under the Act beyond that which exists at the time he or she enters into the agreement." 302 FWS agreed not to pursue take allegations for any taking of RWC that moved into the improved habitat. ${ }^{303}$

The program worked. "No sooner had Safe Harbor been implemented than preemptive clear-cutting [of potential RCW habitat] ceased. Landowners couldn't enroll fast enough." 304 The program answered several

298. See Robert Bonnie, Safe Harbor for the Red-Cockaded Woodpecker, J. Forestry, Apr. 1997, at 20.

299. Availability of an Environmental Assessment and an Application for an Incidental Take Permit to Implement the Red-cockaded Woodpecker "Safe Harbor" Program in the Sandhills Region of North Carolina, 60 Fed. Reg. 10,400, 10,400-01 (Feb. 24, 1995).

300. S.L. Miller et al., North Carolina Sandhills Red-Cockaded Woodpecker Safe Harbor Program: Current Status \& Lessons Learned 4 (2004).

301. Toombs, supra note 274, at 35.

302. Availability of an Environmental Assessment and an Application for an Incidental Take Permit to Implement the Red-cockaded Woodpecker "Safe Harbor" Program in the Sandhills Region of North Carolina, 60 Fed. Reg. at 10,400-01.

303. Id.

304. Ted Williams, Recovery: Saving a Woodpecker Through Research \& Ingenuity, Cool Green ScIEnce (Apr. 3, 2018), https://blog.nature.org/science/2018/04/03/recoverysaving-a-woodpecker-through-research-ingenuity/ [http://perma.cc/8QL8-5MK3]. 
needs, increasing private landowner participation in conservation and at the same time respecting the private property interests that were driving much of the congressional disgruntlement with the Act.

As soon as the Southeast Regional Office launched its Safe Harbor Program, the program began replicating throughout FWS. FWS completed a second agreement in 1995 and a third in 1996, both through its Southwest Regional Office. ${ }^{305}$ By 1997, the national FWS office began the process of making Safe Harbor Agreements official FWS policy. ${ }^{306}$ After promulgation of the final safe harbor rules in 1999, ${ }^{307}$ the Safe Harbor Program exploded in popularity. As of April 2018, one hundred Safe Harbor Programs have been approved, most including a large number of landowners, all together covering well north of 100 million acres. ${ }^{308}$

\section{Evidence for Legal Evolution from the Safe Harbor Program}

This program marks a clear administrative evolution of the ESA. Despite widespread agreement that portions of the Act needed revision in the early 1990s, Congress was gridlocked. ${ }^{309}$ Prior political pressure over private property concerns had produced significant revisions to the Act in the past, including the creation of the incidental take permits in 1982,310 but the partisan (and intra-party) splits in Congress made such action impossible in the 1990s. Facing a hostile Congress and a growing property rights movement, Secretary of the Interior Bruce Babbitt pushed FWS to change the way it administered the ESA in order to coopt the legislative efforts to amend the Act. ${ }^{311}$ Secretary Babbitt "perceived that a major reason the Act was foundering was that it was not being administered with an eye toward success-when success was measured not only by effectiveness in protecting species, but also by common sense principles of ad-

305. U.S. Fish \& Wildlife Serv., Conservation Plans by Type and U.S. FWS Region, Envtl. Conservation Online Sys., https://ecos.fws.gov/ecp0/conservationPlan/ [http:// perma.cc/669X-3FRY ] (last visited July 22, 2018).

306. Announcement of Draft Safe Harbor Policy, 62 Fed. Reg. 32,178, 32,178-01 (June 12, 1997).

307. Safe Harbor Agreements and Candidate Conservation Agreements with Assurances, 64 Fed. Reg. 32,706, 32,706-01 (June 17, 1999).

308. U.S. Fish \& Wildlife Serv., supra note 305.

309. Leshy, supra note 278, at 213 ("Although matters needed fixing, Congress was sorely divided, hopelessly divided as it turned out, on what should be done.").

310. Darcy H. Kishida, Safe Harbor Agreements Under the Endangered Species Act: Are They Right for Hawai'i, 23 U. Haw. L. Rev. 507, 508 (2000) ("In an attempt to assuage disgruntled landowners, Congress amended the ESA in 1982 to be more flexible. Landowners can now obtain a conditional 'incidental take permit,' which allows the holder to 'take' endangered species subject to certain mitigation requirements."); Srinath Jay Govindan, Taking Steps to Protect Private Property and Endangered Species: Constitutional Implications of Habitat Conservation Planning After Dolan v. Tigard, 47 EMORY L.J. 311, 311 (1998) ("Congress soon realized that the ESA in its original form impinged too greatly upon the rights of individual landowners. ... As a result, the ESA was amended in 1982 to provide an opportunity for landowners to reduce the harsh result of the law.").

311. See, e.g., Bruce Babbitt, The Endangered Species Act \& Takings: A Call for Innovation Within the Terms of the Act, 24 ENVTL. L. 355, 367 (1994) ("Controversy about the ESA is not due to deficiencies in the ESA itself; rather, it is the willful failure of public officials to use the Act.”). 
ministration that could enlist rather than alienate public opinion." 312 To Secretary Babbitt, the fix was simple. "He judged that a series of reforms could be implemented unilaterally and consistently with the statute, which would accomplish both goals." 313 The Administration undertook a transformation of the Act through administrative means, knowing that they were altering the Act's fundamental structure "through habitat conservation plans, safe harbor agreements, candidate conservation agreements, and other tools. Many of these devices were crafted without express sanction in the statute." 314 During the ESA's reauthorization fight, amidst a changing and challenging political climate, in a time when the Act would normally evolve through statutory amendments, 315 the administrators of the ESA undertook an administrative evolution of the Act rather than allow Congress to fundamentally alter the super statute itself.

The growth of the Safe Harbor Program is analogous to proliferation of a successful trait through a population. The Services faced strong pressures on all their programs to develop better ways to work with private landowners, and ideas abounded for potential policy improvements. ${ }^{316}$ These variations came both from within FWS and through outside commentators, and included habitat trading, ${ }^{317}$ economic incentives,, 318 memoranda of agreement, ${ }^{319} \mathrm{HCPs},{ }^{320}$ and myriad other options. ${ }^{321}$ From these ideas, the Safe Harbor Program emerged as the clear winner. MOAs and HCPs, the two easiest options under the existing statutory framework, tended to provide insufficient protection and offered little to smaller landowners. But, as one EDF lawyer noted, "[w]hile there is

312. Leshy, supra note 278 , at 213.

313. See id.; see also U.S. Fish \& Wildlife Serv., The Administration's 10-Point Plan for the Endangered Species ACt (1995), https://www.fws.gov/policy/npi96_06 .html [http://perma.cc/J89R-UDA8] (setting out the Administration's plan to improve the Act by "exercising greater administrative flexibility to minimize socioeconomic effects and assure fair treatment for landowners," among other changes).

314. Leshy, supra note 278 , at 213-14.

315. Compare History of the Endangered Species Act, BALlOTPEDIA, https://ballotpedia .org/History_of_the_Endangered_Species_Act [http://perma.cc/L8VB-XLLE], with Endangered Species Act: A History of the Endangered Species Act of 1973, U.S. FisH \& WILDLIFE SERV., https://www.fws.gov/endangered/laws-policies/esa-history.html [http://perma .cc/2A27-V685] (showing that most ESA amendments occurred during the Act's reauthorizations).

316. Herein lies a major difference between traditional biological evolution and legal evolution. Organisms under strong selection are unlikely to produce a wide array of possible solutions to the evolutionary problem, precisely because it is under strong selection. Social systems have the advantage here, in that they can increase the variation in the face of selection.

317. Robert Bonnie \& Micheal Bean, Habitat Trading for Red-Cockaded Woodpeckers: Enhancing Recovery, Reducing Conflicts, 13 Endangered Species update 7, 7-9 (1996).

318. Elizabeth T. Kennedy et al., New Directions for Red-Cockaded Woodpecker Habitat Conservation: Economic Incentives, J. Forestry, Apr. 1996, at 22-26.

319. Ralph Costa, The US Fish \& Wildlife's Red-Cockaded Woodpecker Private Lands Conservation Strategy: An Evaluation, 14 EndANGEREd Species update 40, 40 (1997).

320. Id.

321. Environmental Defense Fund, A Report to the Bernice Barbour, Beneficia, Underhill, and the National Fish and Wildlife Foundations, in INCENTIVES FOR ENDANGERED Species Conservation: Opportunities in the Sandhills of North Carolina (1995). 
much to criticize about the FWS's other approaches to RCWs on private lands, the Safe Harbor program has to date been an immense success for both landowners and RCWs." 322 In light of the program's success, it quickly proliferated throughout the agency, spreading first to other regions and then, eventually, becoming formal policy at the national level. It displaced other less successful program. This follows the biological paradigm - variation, selection, and inheritance.

The program is also an example of a panda's thumb, something old pressed into service in a new and unexpected way. The FWS created the Safe Harbor program out of whole cloth, with no explicit statutory backing. The program builds on take permits that were part of the original ESA in 1973, which allowed take "to enhance the propagation or survival of the affected species" under Section 10(a)(1)(A). ${ }^{323}$ This authority, delegated to the regional office with some guidance from the Safe Harbor Policy, ${ }^{324}$ allows the Services to

encourage private and other non-Federal property owners to implement conservation efforts for listed species by assuring property owners they will not be subjected to increased property-use restrictions if their efforts attract listed species to their properties or increase the numbers or distribution of listed species already present on their properties. ${ }^{325}$

In short, the Services and the landowner negotiate a Safe Harbor contract outlining the improvements that the landowner will make to listed species habitat on the landowner's property, and the landowner gets an enhancement of survival permit from the relevant regional office. ${ }^{326}$

Although the Services rely on Section 10(a)(1)(A) as authority for the Safe Harbor Program, "there is no evidence that Congress intended to authorize FWS to enter into long term contracts waiving the government's regulatory authority in this fashion." 327 The statute simply does not envision this kind of allowance for take, or for take coupled with potentially transitory benefits (as when a landowner returns the property

322. Robert Bonnie, Strategies for Conservation of the Endangered Red-Cockaded Woodpecker on Private Lands, 14 Endangered Species update 45, 46 (1997).

323. Endangered Species Act, 16 U.S.C. $\S ~ 1539(a)(1)(A)-(B)(2012)$ ("The Secretary may permit, under such terms and conditions as he shall prescribe (A) any act otherwise prohibited by Section 9 [Endangered Species Act, 16 U.S.C. $\$ 1538$ (2012)] for scientific purposes or to enhance the propagation or survival of the affected species").

324. U.S. Fish \& Wildlife Serv., Permits for Native Species Under the Endangered Species Act, https://www.fws.gov/endangered/esa-library/pdf/permits.pdf [http://perma.cc/ 4U24-U4VU] (last visited Feb. 9, 2019) (noting that regional offices issue most permits for native listed species).

325. Safe Harbor \& Candidate Conservation Agreements, 64 Fed. Reg. 32,706, 32,707 (June 17, 1999).

326. Announcement of Final Safe Harbor Policy, 64 Fed. Reg. 32,717, 32,717 (June 17, 1999). This Announcement provides additional details.

327. Patrick A. Parenteau, Rearranging the Deck Chairs: Endangered Species Act Reforms in an Era of Mass Extinction, 22 WM. \& MARY EnvtL. L. \& POL'y Rev. 227, 287 (1998). 
to the baseline). ${ }^{328}$ Thus, this is "the kind of jury-rigged adaptation that characterizes evolutionary phenomena." 329 Constrained by the ESA, FWS found a new way to use old law and created a new program to meet a pressing need. Absent their constraints, FWS would have sought congressional approval for the new program and begun with a new statutory authorization. But they could not, and so they made do with the authority they had. The locus has shifted, but the legal evolution continues.

In contrast to the federal approach of allowing the Act to evolve via administrative action, the several states that have embraced the safe harbor approach made similar changes using legislation. Three of the four states with safe harbor programs (California, Hawaii, Kansas, and Florida) have legislatively authorized their safe harbor programs, with Florida being the lone exception. ${ }^{330}$ California added an explicit safe harbor provision to its California Endangered Species Act (CESA) - Fish and Game Code Section 2089.2331 -in 2009.332 Although the state already honored federal ESA permits not inconsistent with the CESA ${ }^{333}$ and allowed take permits by individuals for management purposes, ${ }^{334}$ the bill's author argued that "legislation is clearly needed . . . to provide certainty to landowners that [Fish and Game] is acting with complete authority." 335 The state's take permitting authority already granted under CESA was at least as broad as the federal take permitting authority, but, in a state with a legislature that readily amends the CESA when warranted, ${ }^{336}$ a legislative amendment must have seemed the proper course for the creation of an entirely new permitting program. Similarly, the Hawaiian Endangered

328. See Richard B. Stewart, A New Generation of Environmental Regulation?, 29 CAP. U. L. REv. 21, 78 (2001) (discussing analogous HCP requirements, and arguing that "[p]rograms differ substantially in the amount of legal certainty that their agreements provide to regulated parties when there is no explicit statutory authority for the agency to modify default requirements by these agreements."); see also Michael J. Bean, New Landowner Incentive Tools for Encouraging Conservation Efforts Under the Endangered Species Act, 13 A.L.I.-A.B.A. 103, 108 (2006) ("Recurrent proposals to 'codify' authority for Safe Harbor Agreements have been made, but existing authority is not in doubt."); Jonathan H. Adler, Back to the Future of Conservation: Changing Perceptions of Property Rights \& Environmental Protection, 1 N.Y.U. J. L. \& LiberTy 987, 1010-11 (2005). Note also that Michael Bean, the author of several of these updates, helped develop the Safe Harbor Program. The statute does not appear to explicitly bar this kind of agreement, and the approach appears to have gone unchallenged. Research uncovered no cases directly challenging the statutory basis for the Safe Harbor Program.

329. Sinclair, supra note 12, at 456.

330. See Fla. Stat. Ann. § 379.2291(2) (West 2017); see also id. § 379.1025 (Florida has virtually no content in its statutory endangered species act, instead giving the Florida Fish $\&$ Wildlife Commission great discretion. The Commission is created and empowered by the Florida State Constitution Art. IV, § 9).

331. CAL. Fish \& Game Code $\S \S 2050-2115.5$ (West 2017).

332. Id. § 2089.2.

333. Id. § 2080.1(c).

334. Id. § 2081.1(a).

335. Cal. Senate Rules Committee, Analysis of Senate Floor Bill No. 448, at 7 (Sept. 2, 2009).

336. California has amended the CESA over forty times. See CAL. Fish \& GAme Code $\S \S 2050-2115.5$ (West 2017) (see collected citations in the Historical and Statutory Notes section). 
Species Act (HESA) has, since at least 1988, possessed the authority to allow the take "of any species of aquatic life, wildlife, and land plant for the purpose of conserving the same," 337 where "conserve" means "to use ... all methods and procedures which are necessary to bring any endangered species or threatened species to the point at which the measures provided pursuant to this chapter and the Endangered Species Act are no longer necessary." 338 Nevertheless, Hawaii explicitly amended the HESA to create a state-level Safe Harbor Program in 1997.339 Again, Hawaii frequently amends the HESA when conditions warrant it. ${ }^{340}$ Finally, the Kansas legislature has, since at least 1989, given its agencies the same authority the Services used to create the federal Safe Harbor program. ${ }^{341}$ Nevertheless, Kansas explicitly amended its act in 1997 to create a Safe Harbor Program. ${ }^{342}$ Kansas has amended its act only four times since its passage in $1975.3^{343}$ These states show a clear trend. In places where the underlying endangered species statute has not ossified, endangered species acts tended to evolve via legislative changes. At the federal level, this same degree and type of change necessarily grew from administrative evolution of the law because the legislature could not successfully amend the federal statute.

\section{Evolution of Experimental Populations}

The ESA provides several mechanisms for the reintroduction of listed species. ${ }^{344}$ Congress added one reintroduction method, the experimental population approach, in $1982^{345}$ for the express purpose of easing social and political pressures around reintroductions. ${ }^{346}$ Under this mechanism, the Services may reintroduce a listed species to the wild with a reduced suite of protections, easing concerns that nearby resource users might have to change their status quo to avoid violations of the Act. For nones-

337. Haw. Rev. Stat. Ann. § 195D-3 (West 2017).

338. Id. § 195D-2.

339. See id. at § 195D-22; see also Kishida, supra note 310, at 549.

340. Hawaii has amended its statute over twenty times. See Haw. Rev. Stat. Ann. $\S 195$ D-1-32 (West 2017) (see collected citations in the Historical and Statutory Notes section).

341. Kan. Stat. Ann. § 32-961 (West 2017) (allowing the administrators of the Kansas version of the Endangered Species Act to permit take to "enhance the propagation or survival of the affected species"). This mirrors the ESA language exactly. See Endangered Species Act, 16 U.S.C. $\$ \S 1539(a)(1)(A)-(B)$ (2012) ("The Secretary may permit, under such terms and conditions as he shall prescribe (A) any act otherwise prohibited by Section 1538 [Endangered Species Act, 16 U.S.C. $\$ 1538$ (2012)] for scientific purposes or to enhance the propagation or survival of the affected species").

342. See 1997 Kan. Sess. Laws Ch. 113; see also Kan. Stat. Ann. § 32-962 (West 2017).

343. See Kan. Stat. Ann. § 32-962 (see collected citations in the Historical and Statutory Notes section).

344. Karrigan Börk, Note, Listed Species Reintroductions on Private Land-Limiting Landowner Liability under the Endangered Species Act, 30 STAn. EnVTL. L.J. 177 (2011).

345. Endangered Species Act Amendments of 1982, Pub. L. No. 97-304, 96 Stat. 1411.

346. See H.R. ReP. No. 97-567, at *34 (1982), reprinted in 1982 U.S.C.C.A.N. 2807, 2834 (noting the legislation will ease restrictions where "the release of these populations will continue to be frustrated by public opposition"); see also Holly Doremus, Restoring Endangered Species: The Importance of Being Wild, 23 Harv. Envtl. L. Rev. 1, 20 (1999). 
sential experimental populations, ${ }^{347}$ the Act suspends many of its protections, including critical habitat designations, the formal consultation requirements under Section 7, and the automatic take protections under Section 9.348 In place of these automatic protections, the Services promulgate regulations on a case-by-case basis, allowing both incidental and intentional take of these reintroduced populations. ${ }^{349}$ "[S]ection 10(j) is a tool with one purpose ... to relax the protections otherwise provided by the Endangered Species Act." 350 As of January 2018, FWS reports sixtyfour experimental population reintroductions, although this total excludes NMFS reintroductions. ${ }^{351}$ Professor Frederico Cheever has written the seminal work on experimental populations, ${ }^{352}$ so this article limits its discussion to the aspects of the program that demonstrate an evolution of the Act by the Services.

\section{Pitfalls of Experimental Populations}

For all the good this provision has done, enabling such controversial reintroductions as the red wolf,, ${ }^{353}$ the Mexican wolf, ${ }^{354}$ the Rio Grande silvery minnow, ${ }^{355}$ the black footed ferret, ${ }^{356}$ whooping cranes, ${ }^{357}$ and myriad other species, it raises significant risks for listed species. The experimental population designation includes not only the reintroduced individuals, but "any offspring arising solely therefrom." 358 The Act provides no automatic trigger for removal of the experimental population designation and does not explicitly provide the Services with the power to remove this designation. ${ }^{359}$ Finally, the Services have interpreted the Act

347. Endangered Species Act 16 U.S.C. $§ 1539(j)(2)(B)$ (2012) (noting that the Services must, "determine, on the basis of the best available information, whether or not [the reintroduced] population is essential to the continued existence of an endangered species or a threatened species."). Thus far, no populations have been deemed essential.

348. Id. § 1539(j)(2)(C).

349. See H.R. ReP. No. 97-567, at *34.

350. Federico Cheever, From Population Segregation to Species Zoning: The Evolution of Reintroduction Law Under Section 10(J) of the Endangered Species Act, 1 Wyo. L. Rev. 287, 306 (2001).

351. U.S. Fish \& Wildlife Serv., Species Reports: Experimental Populations (2018), available at http://ecos.fws.gov/tess_public/pub/experimentalPopulations.jsp [http:// perma.cc/29FS-PVRX].

352. Cheever, supra note 350, at 287.

353. 50 C.F.R. $\$ 17.84(c)$ (2017) (allowing take of wolves in the act of killing livestock or even wolves simply found on private property, in some cases, among other allowable takes).

354. Id. $\$ 17.84(\mathrm{k})$ (allowing take of wolves in the act of killing livestock; wolves simply found on private property, in some cases; and wolves having an undue impact on big game animals, among other allowable takes).

355. Id. $\S 17.84(\mathrm{u})(2)(\mathrm{i})$ (allowing all incidental take associated with "the carrying out of an otherwise lawful activity, such as recreation (e.g., fishing, boating, wading, trapping, or swimming), agriculture, and other activities that are in accordance with Federal, State, and local laws and regulations").

356. Id. $\S 17.84(\mathrm{~g})$.

357. Id. $\S 17.84(\mathrm{~h})(2)$ (allowing take "accidental and incidental to an otherwise lawful activity").

358. 16 U.S.C. $\$ 1539(\mathrm{j})(1)(2012)$.

359. See id. § $1539(\mathrm{j})$. 
to allow them to remove protections from any individual of a listed species that enters the area where an experimental population of that species has been established. ${ }^{360}$ In essence, then, the experimental population designation has the potential to undercut the very purpose of the Actthe recovery of wild, unmanaged populations of listed species.

The Act recognizes this threat. It circumscribes the power of the Services to create experimental populations by providing several requirements for experimental populations. ${ }^{361}$ Central to this article's analysis, the Services may create an experimental population "only when, and at such times as, the population is wholly separate geographically from nonexperimental populations of the same species," 362 and only "outside the current range of such species." 363 This "geographic isolation" requirement should substantially circumscribe the use of the experimental population designation. But the Services have essentially read the requirement out of the Act. The experimental population designation has become so essential to Service efforts to reintroduce species in the face of political or social opposition, they have, in effect, changed the law to permit the unbridled use of experimental populations. This is a prime example of the Service evolving the law beyond the limits of the statute.

\section{Changing the Experimental Populations Requirements}

Professor Cheever's paper documents this evolution. As he describes it, "[i]nitially, USFWS ... embrac[ed] the notion of population separation as a legal 'requirement' and undertook active population segregation. However, over time, as USFWS began contemplating more complex reintroductions with greater chances of population overlap, it began adopting a more flexible approach to the notion of geographical separation." ${ }^{364}$ In an early experimental population reintroduction, FWS reintroduced the red wolf to the Alligator River National Wildlife Refuge in North Carolina in 1987.365 The wolves all wore radio collars, and any wolf leaving the experimental population area was supposed to be recaptured by FWS for transportation back to the designated area. FWS was resolved to maintain geographic isolation from any other potential populations.

360. See, e.g., 50 C.F.R. $§ 17.84(x)(2)$ (ii) ("Any wood bison found within the Alaska wood bison [nonessential experimental population] area will be considered part of the [nonessential experimental population]."); id. § 17.84(p)(9)(ii) ("All falcons found in the wild within the boundaries of the [nonessential experimental population] area after the first releases will be considered members of the [nonessential experimental population]."); id. § 17.84(g)(9)(ii) ("Any black-footed ferret found in the wild within these counties will be considered part of the nonessential experimental population after the first breeding season following the first year of releases of black-footed ferret.").

361. See 16 U.S.C. \$ 1539(j).

362. See id. § 1539(j)(1); see also Wyoming Farm Bureau Fed'n v. Babbit, 199 F.3d 1224, 1232 (10th Cir. 2000).

363. 16 U.S.C. $\$ 1539(\mathrm{j})(2)(\mathrm{A})$.

364. Cheever, supra note 350 , at 320.

365. Determination of Experimental Population Status for an Introduced Population of Red Wolves in North Carolina, 51 Fed. Reg. 41,790, 41,790 (Nov. 19, 1986) (to be codified at 50 C.F.R. pt. 17). 
The latest wolf reintroduction, the gray wolf in Yellowstone National Park, contrasts with this early effort. FWS planned to reintroduce an experimental population of gray wolves in Yellowstone National Park and central Idaho, ${ }^{366}$ areas where isolated wolves and some small packs already existed, even absent the reintroduction. ${ }^{367}$ To bring this reintroduction effort within the statutory confines of the ESA, that is, to ensure that the reintroduced "population is wholly separate geographically from nonexperimental populations of the same species," 368 and "outside the current range of such species," 369 FWS simply redefined the term "wolf population." Under its new definition, a population required "at least two breeding pairs of gray wolves that each successfully raise at least two young to December 31 of their birth year for 2 consecutive years." ${ }^{370}$ In FWS's view, this definition ensured that individual wolves or even a single family of wolves could interact with the reintroduced population without endangering its experimental status. Both the Ninth and Tenth Circuits have upheld this sleight of hand. ${ }^{371}$

In 2010, the Tenth Circuit again blessed the Services' approach, ${ }^{372}$ upholding the experimental reintroduction of Northern Aplomada Falcons in New Mexico, well within flying range of an established population of the same falcons. ${ }^{373}$ FWS admitted "it would be virtually impossible to preclude naturally occurring individual falcons from intermingling with the experimental population," 374 and the Court noted that FWS' conclusion that there was no geographic overlap was one of "two fairly conflicting views." 375 Nevertheless, the Court ultimately deferred to FWS's expertise and responsibility for administering the Act. ${ }^{376}$

366. Establishment of a Nonessential Experimental Population of Gray Wolves in Central Idaho \& Southwestern Montana, 59 Fed. Reg. 60,266, 60,266 (Nov. 22, 1994) (to be codified at 50 C.F.R. pt. 17); Establishment of a Nonessential Experimental Population of Gray Wolves in Yellowstone National Park in Wyoming, Idaho, and Montana, 59 Fed. Reg. 60,252, 60,252 (Nov. 22, 1994) (to be codified at 50 C.F.R. pt. 17).

367. Establishment of a Nonessential Experimental Population of Gray Wolves in Central Idaho \& Southwestern Montana, 59 Fed. Reg. at 60,266.

368. 16 U.S.C. § 1539(j)(2) (2012); see also Wyoming Farm Bureau Fed'n v. Babbit, 199 F.3d 1224, 1232 (10th Cir. 2000).

369. 16 U.S.C. $§ 1539(\mathrm{j})(2)(\mathrm{A})$.

370. Establishment of a Nonessential Experimental Population of Gray Wolves in Central Idaho \& Southwestern Montana, 59 Fed. Reg. at 60,266-01.

371. United States v. McKittrick, 142 F.3d 1170, 1175 (9th Cir. 1998); Wyo. Farm Bureau Fed'n, 199 F.3d at 1234 . The district court rejected the approach but was overturned by the Tenth Circuit. See Wyo. Farm Bureau Fed'n v. Babbitt, 987 F. Supp. 1349, 1373. (D. Wyo. 1997) ("[T]he mere fact that Defendants have drawn a line which purports . . between the existing wolf population in Montana and either of the proposed experimental population areas is insufficient and contrary to law.").

372. Forest Guardians v. U.S. Fish \& Wildlife Serv., 611 F.3d 692, 707-08 (10th Cir. 2010).

373. Id. at 701 .

374. Id. (citing Establishment of a Nonessential Experimental Population of Northern Aplomado Falcons in New Mexico and Arizona, 71 Fed. Reg. 42,298, 42,300 (July 26, 2006) (to be codified at 50 C.F.R. pt. 17)).

375. Id. at 709 .

376. Id. at 710 . 
Finally, NMFS's reintroduction of spring run Chinook salmon to the San Joaquin River as an experimental population exemplifies how far the Services' definition of experimental population has evolved from the geographic isolation requirements. Pursuant to a settlement agreement enabled by California Fish and Game Code Section 5937,377 on the San Joaquin River below Friant Dam, NMFS agreed to reintroduce spring run Chinook to the San Joaquin by 2012. Friant Dam dried the riverbed below the dam for roughly sixty miles, but the settlement agreement also required the Bureau of Reclamation to return water to the river. This rewatering and reintroduction effort is the largest ever. It is an unprecedented effort.

The reintroduction of threatened spring run Chinook raised significant concerns for Friant Dam's downstream landowners and water users. ${ }^{378}$ In response, NMFS suggested reintroducing the spring run Chinook as an experimental population, and the settlement agreement ultimately followed that course. The experimental population designation determined "all CV spring-run Chinook salmon, including those that have been released or propagated, naturally or artificially, within the experimental population area" in the San Joaquin River are considered part of the San Joaquin River experimental population. ${ }^{379}$ Rather than try to track the reintroduced population, NMFS simply drew a circle and said anything in that circle is by law experimental. This conflicts with the Act, because there were already spring run fish in the area. ${ }^{380}$ Moreover, the experimental population will join with other salmon populations in the ocean. There are no provisions in the Act allowing for only temporary isolation of experimental populations. This experimental population inarguably lacks any real geographic isolation and is clearly not "outside the current

377. Nat. Res. Def. Council v. Rodgers, 381 F. Supp. 2d 1212 (E.D. Cal. 2005). The terms of this settlement were later approved by Congress through its enactment of the San Joaquin River Restoration Settlement Act. See Joaquin River Restoration Settlement Act, Pub. L. No. 111-11, §10011, 123 Stat. 1349 (2009).

378. See, e.g., Kimberly Geiger, San Joaquin River plan stalls in House / Lawmakers balk—some water users weren't part of talks, SFGATE (Sept. 22, 2006), http://www.sfgate .com/green/article/WASHINGTON-San-Joaquin-River-plan-stalls-in-2469354.php [http:// perma.cc/HN67-DTAK].

379. Endangered Threatened Species: Designation of a Nonessential Experimental Population of Central Valley Spring-Run Chinook Salmon Below Friant Dam in the San Joaquin River, CA, 50 Fed. Reg. 79622 (Dec. 31. 2013) (codified at 50 C.F.R. pt. 223).

380. Although salmon generally return to their natal streams to spawn, they do not always succeed in finding their home rivers. Those fish that do not return to their natal river, termed "strays," fulfill important evolutionary roles, maintaining genetic connections between large metapopulations of salmon and recolonizing streams where local populations have been extirpated. QuINN, supra note 224, at 91. Like any salmon population, the spring run Chinook salmon in the Central Valley stray. The northern half of the Central Valley hosts several separate populations of spring run Chinook, and for years portions of these populations have shown up in the southern half of the Central Valley, in many tributaries of the San Joaquin, according the NMFS data. NAt'L MARINE Fisheries SERV., 5-Year Review: Summary and Evaluation of Central Valley Spring-run ChinOok Salmon Evolutionarily Significant Unit (2011), available at https://reposito ry.library.noaa.gov/view/noaa/17018. These strays will almost certainly enter the experimental population area as it is re-watered and the habitat there improves. 
range" of such species, as required for an experimental population designation to comply with the Act. ${ }^{381}$

Nevertheless, the reintroduction has gone forward as an experimental population, and the special regulations allow any unintentional, nonnegligent take of the salmon in the experimental population areas. ${ }^{382}$ For example, salmon may be killed during normal irrigation operations or while driving through informal low water crossings in the streambed, both without violating the Act. This reduces protection for salmon that were not part of the reintroduced population. Regardless, based on the precedent discussed above and the buy-in to the reintroduction effort from many, perhaps most, potential litigants, NMFS's decision seems unlikely to be overturned. Through deference by the courts and due to public demand or acquiescence, the Services have effectively altered the Act's requirements for experimental populations, which amounts to another evolution of the Act itself.

\section{Evidence for Legal Evolution from the Experimental Population Reintroductions}

The reintroduction of the spring run Chinook to the San Joaquin is particularly telling because, as with the Safe Harbor program, it juxtaposes the ESA, with its political gridlock, with CESA, which does not suffer the same degree of controversy. Spring run Chinook are listed as threatened, and likewise protected from take, under CESA. CESA does not allow designation of populations as experimental populations ${ }^{383}$ and so did not provide the California Department of Fish and Wildlife (CDFW) with a mechanism to exempt the introduction. Nevertheless, CDFW secured an amendment to CESA to allow any take permitted under the federal experimental population designation. ${ }^{384}$ In this context of a functioning legislative system for evolving the law, the California legislature amended CESA to improve its function in light of changing societal needs, a stark contrast from the federal legislature's failure to address experimental populations and the Service's subsequent evolution of the ESA on their accord. ${ }^{385}$

381. H.R. REP. No. 97-567, at 33 (1982) ("II]n the case of the introduction of individuals of a listed fish species into a portion of a stream where the same species already occurs, the introduced specimens would not be treated as an 'experimental population' separate from the non-introduced specimens.").

382. 50 C.F.R. $§ 223.301(b)(4)(i)(2017)$.

383. Cal. Fish \& Game Code $\S \S 2080,2081$ (West 2017).

384. Id. $\$ 2080.4$ ("If a population of spring run Chinook salmon in the San Joaquin River is designated as an experimental population under subsection (j) of Section 1539 of Title 16 of the United States Code, no further authorization or approval is necessary under this chapter for any person to incidentally take members of that experimental population").

385. Implementation of the settlement agreement also required a federal act, the San Joaquin River Restoration Settlement Act, Pub. L. No. 111-11, §§ 10001-10203, 123 Stat. 992 (2009), but that act avoided any amendment of underlying environmental laws, including the ESA. Congress directed the Services to "comply with all applicable Federal and State laws, rules, and regulations, including the National Environmental Policy Act of 
More broadly, the Services' approach to experimental population seems to be a clear example of evolution in the law, evolving from the statutory definition, or at least an administrative definition that honored the statutory definition, to a definitional approach that honored the statute only in the breach. The Services employed a variety of strategies in the early reintroduction efforts, until they found an approach that fit within their resource and political constraints and the courts ultimately approved that approach. This is the variation and selection. They continued that successful approach, with slight variations, for later reintroductions, including the falcon and the salmon. This is the inheritance.

Indeed, Professor Cheever's article uses evolutionary terms to tell the story of this progression, even using the term "evolution" in his title. But his approach is ultimately not an evolutionary approach to the law itself, but rather uses the evolutionary approach as a way to tell the story of the experimental population. The article draws no explicit parallels to the biological process of evolution and provides no evolutionary analysis. What, then, does an evolutionary analysis tell us about administrative law?

\section{PRACTICAL IMPLICATIONS OF THE THEORY OF ADMINISTRATIVE EVOLUTION OF THE LAW}

Drawing conclusions from a preliminary study of one statute using a nascent legal approach is risky, but this preliminary analysis points the way to at least a few conclusions. First, it suggests administrative evolution of the law is simply the reality for many statutes, particularly changeresistant super statutes like the ESA. ${ }^{386}$ This is not terribly surprising, given the legislature's inability to make changes to these laws and the courts' determination not to make policy decisions for agencies. ${ }^{387} \mathrm{Al}-$ though environmental lawmaking, at least, seems to be marked by occasional bursts of legislative action (the early 1970s and perhaps the early 1990s, for example), the long interstitial periods still see significant legal evolution of the law by administrative rulemaking. While this nonlinear

1969 ... and the [ESA]." San Joaquin River Restoration Settlement Act § 10006(a)(1). Congress seems to prefer that the Services push beyond the Act on their own, carrying out the administrative evolution of the law, rather than take on that political hot potato themselves.

386. See Michael Ray Harris, Breaking the Grip of the Administrative Triad: Agency Policy Making Under A Necessity-Based Doctrine, 86 Tul. L. Rev. 273, 275 (2011) (acknowledging that "[t]he continued existence of . . . a policy-wielding bureaucracy in America is not subject to doubt").

387. This reality also has implications for the evolutionary approach to administrative law. Ruhl suggests that one should measure fitness by how well a law fulfills its policy, in hopes that "the fitness of a normatively undesirable law-a law the policy for which no longer is (or perhaps never was) one we wish to pursue in the sociolegal system-may lead us to consider the need for modifying or repealing the law more immediately and more thoroughly than if the law were relatively unfit." Ruhl, supra note 21, at 1451-52. But this measure of fitness does not advance the study of evolution via administrative lawmaking, since the underlying laws are so resistant to change as to be permanent. 
lawmaking pattern is an acknowledged phenomenon in public law, ${ }^{388} \mathrm{ev}-$ olutionary approaches have largely overlooked the continued gradual growth in the environmental law via administrative action.

Second, given this reality, advocates for change in the law would be best advised to aim for administrative fixes, following Secretary Babbitt's model with the Endangered Species Act. Recent administrations have taken this approach with significant success ${ }^{389}$ and legal academics have been exploring this approach for some time. This, perhaps, gives theoretical backing to that approach. This does raise questions about the evolutionary metaphor when administrations abruptly change policies, as seen in the climate change policies of the Bush, Obama, and Trump administrations. Such rapid change in selective environments is not outside the scope of an evolutionary explanation of administrative law, and the administrative actions involved in these shifts are still subject to the evolutionary constraints identified here (e.g. path dependent, incremental change, etc.), but more work is needed in this area.

Third, the consideration of agency administration as an evolutionary process also suggests several changes that would increase the rate of evolution. At the outset, this assumes that increased evolution of the law by agencies is a normatively good thing. This is, to put it mildly, not a universal position. Administrative agencies are often criticized as "unwieldy and antidemocratic." 390 Moreover, this view of agencies does little to address concerns raised by the public choice model of administrative law. ${ }^{391}$ And this idea cuts directly against Professor Epstein's view of agencies as a normative, but perhaps sometimes necessary, evil. ${ }^{392}$ Instead, it builds on an admittedly progressive vision that "rests on the key assumption that government officials armed with technical expertise and acting in good faith to advance the public interest can systematically out-

388. Hornstein, supra note 20, at 932 (noting "the literature on 'republican moments,' which are defined as extraordinary periods when broad segments of the electorate suddenly become intensely interested in a political issue, causing legislators to enact statutes that are far more in line with public values than special interest models would predict").

389. E.g., Elena Kagan, Presidential Administration, 114 Harv. L. Rev. 2245, 2248 (2001) (noting that "Clinton and his White House staff turned to the bureaucracy to achieve, to the extent it could, the full panoply of his domestic policy goals").

390. Melissa Mortazavi, Rulemaking Ex Machina, 117 Colum. L. Rev. Online 202, 204 (2017).

391. See Jim Rossi, Public Choice Theory and the Fragmented Web of the Contemporary Administrative State, 96 Mich. L. Rev. 1746, 1754 (1998); Jerry L. Mashaw, Greed, Chaos, \& Governance: Using Public Choice to Improve Public Law (Yale U. Press 1997); Nina A. Mendelson, Agency Burrowing: Entrenching Policies and Personnel Before A New President Arrives, 78 N.Y.U. L. Rev. 557, 587 (2003) ("[A]gencies could be biased toward well-organized, more narrowly focused interest groups, since those groups may be especially able to provide regulators with information valuable to the agency or to invoke discipline by political branches."); see also Sanford N. Caust-Ellenbogen, Blank Checks: Restoring the Balance of Powers in the Post-Chevron Era, 32 B.C. L. Rev. 757, 814 (1991).

392. Epstein, supra note 55, at 494 (arguing for the adoption of "structures that make it more difficult to pass and implement legislation, in the uncertain hope that this more arduous process will be more likely to weed out factional reforms of dubious merit than genuine social improvements" and suggesting that review should begin with the an assumption against state action). 
perform any system of limited government whose major function was to support and protect market institutions." ${ }^{393}$ From this vantage point, assuming the original purposes of the relevant statute remain a significant selective pressure on regulations and assuming this pressure is relatively constant over time, such an increase would be expected to lead to normatively "better" regulations through evolution. ${ }^{394}$ With regard to judicial review, this kind of directional selection might be ensured through a reinvigoration of the zone of interest test's bar on those seeking an outcome "inconsistent with the purposes implicit in the statute," 395 although this prospect seems dim in light of Lexmark International, Inc. v. Static Control Components, Inc. 396

Increased rates of administrative evolution of the law could also partially ameliorate some of the traditional criticisms of the administrative state, particularly the lack of accountability or democratic responsiveness. ${ }^{397}$ Increased evolution in an administrative state would allow increased exposure to the selective agents identified here-internal agency pressure, court challenges, and political pressure from several sources (the public, the legislature, the rest of the executive branch, etc.), which could democratize agency accountability, assuming that these pressures reflect, in some way, the desires of the public. This may not be a safe assumption, and increased rates of evolution may simply allow more opportunities for rent seeking or other regulatory pathologies.

Evolutionary studies teach that many factors influence the rate of evolution, including some that, analogous to administrative law evolution, are open to manipulation. For example, shorter generation times in populations spurs faster evolution. ${ }^{398}$ Intuitively, mutations and recombination that increases genetic diversity occur during reproductive events, and so

393. Id. at 492 .

394. This idea lies at the heart of adaptive management, which aims to improve management (often ecosystem management) through an iterative process of managing, reflecting, and adapting over time. See, e.g., Holly Doremus, Adaptive Management, the Endangered Species Act, \& the Institutional Challenges of New Age Environmental Protection, 41 WASHBURn L.J. 50, 52-53 (2001).

395. See Clarke v. Securities Industry Association, 479 U.S. 388, 399 (1987); see also Kenneth Culp Davis, Administrative Law Treatise § 24.17, at 279 (2d ed. 1983) ("Something resembling the 'zone' test may often be sound. A statute or rule designed to benefit a particular class may not be asserted by nonmembers of the class.").

396. 134 S. Ct. 1377, 1388 (2014); see generally Brannon P. Denning \& Sarah F. Bothma, Zone-of-Interests Standing in Constitutional Cases After Lexmark, 21 LewIS \& Clark L. Rev. 97, 99 (2017).

397. Mendelson, supra note 391, at 661.

398. Andrew P. Martin \& Stephen R. Palumbi, Body Size, Metabolic Rate, Generation Time, \& the Molecular Clock, 90 Proc. NAT'L AcaD. SCI. U.S. Am. 4087, 4088 (1993); Stephen A. Smith \& Michael J. Donoghue, Rates of Molecular Evolution Are Linked to Life History in Flowering Plants, Science, Oct. 3, 2008, at 86, 89; Arne Ø. Mooers \& Paul H. Harvey, Metabolic Rate, Generation Time, \& the Rate of Molecular Evolution in Birds, 3 Molecular Phylogenetics \& Evolution 344, 344 (1994); Jessica A. Thomas et al., A Generation Time Effect on the Rate of Molecular Evolution in Invertebrates, 27 MoLECULAR BIOLOGY \& EVOLUTION 1173, 1176 (although many of these studies address only neutral variation, this last study analyzes both neutral and adaptive variation and finds that shorter generation times increases both). 
more frequent reproductive events lead to more genetic diversity. This genetic diversity is the raw material for evolution. Further, shorter generation times mean that selection within a population occurs more frequently, thus increasing the rate of adaptive evolution. ${ }^{399}$ By analogy, decreasing generation times in rulemaking would also increase the evolutionary rate. This would mean more frequent rulemaking, admittedly an onerous proposition, ${ }^{400}$ but would likely increase the responsiveness of the agency to existing selective pressures. The ESA already imposes requirements of this sort through mandatory reassessment of listed species every five years, ${ }^{401}$ but the administrative costs and missed deadlines associated with this requirement suggest caution in deploying the approach more widely.

At least one form of agency policymaking would stand to benefit from this change. When agencies reinterpret their own longstanding regulations and use the old regulations to come to new, inconsistent conclusions, this amounts to a new rulemaking in function, if not in form. Courts generally grant significant deference, termed Auer or Seminole Rock deference, ${ }^{402}$ to agency interpretations of their own regulations. Under this standard, the reviewing court gives interpretations "controlling weight unless it is plainly erroneous or inconsistent with the regulation." 403 As Justice Roberts has noted, controversies around agency interpretations of their own regulations "arise as a matter of course on a regular basis." 404 Some Supreme Court precedent suggests that an agency loses deference when its new interpretation of a regulation conflicts with longstanding agency practices, ${ }^{405}$ particularly if the new interpretation conflicts with the agency's intent at the time the regulation was promulgated. ${ }^{406}$ In practice, however, courts have not followed this approach as closely as they should. Even the Supreme Court does not appear to follow it terribly closely. ${ }^{407}$ Clearly requiring agencies to conduct a new rulemaking

399. See Thomas et al., supra note 398, at 1178; see also Patrick M. Garry, Accommodating the Administrative State: The Interrelationship Between the Chevron and Nondelegation Doctrines, 38 ARIz. ST. L.J. 921, 948 (2006).

400. Mortazavi, supra note 390, at 207 (discussing the burdensome and almost overwhelming nature of rulemakings in the modern administrative state).

401. 16 U.S.C. $\$ 1533(\mathrm{c})(2)(\mathrm{A})(2012)$.

402. Kevin M. Stack, Interpreting Regulations, 111 Мich. L. REv. 355, 371 (2012) (citing Bowles v. Seminole Rock \& Sand Co., 325 U.S. 410, 414 (1945); Auer v. Robbins, 519 U.S. 452, 461 (1997)).

403. Bowles, 325 U.S. at 414.

404. Decker v. Nw. Envtl. Def. Ctr., 133 S. Ct. 1326, 1339 (2013) (Roberts, C.J., concurring).

405. Christopher v. SmithKline Beecham Corp., 567 U.S. 142, 155 (2012) (noting that "deference is ... unwarranted when there is reason to suspect that the agency's interpretation does not reflect the agency's fair and considered judgment on the matter in question. . . This might occur when the agency's interpretation conflicts with a prior interpretation") (internal citations and quotation marks omitted).

406. Thomas Jefferson Univ. v. Shalala, 512 U.S. 504, 512 (1994).

407. United Student Aid Funds, Inc. v. Bible, 136 S. Ct. 1607, 1608 (2016) (Thomas, J., dissenting). In his dissenting opinion for the Seventh Circuit, Judge Manion explained that the interpretation at issue was "entirely new and inconsistent with [the agency's] prior interpretations." Bible v. United Student Aid Funds, Inc., 799 F.3d 633, 674 (7th Cir. 2015). 
when changing a longstanding interpretation of their own regulations would effectively decrease generation times and increase the rate of administrative evolution of the law.

Evolutionary biology also indicates a strong correlation between rates of adaptive evolution and population size. ${ }^{408}$ Again, this is intuitive. Larger populations allow more opportunity for the advent of genetic variation within the population, increasing the feedstock available for evolutionary processes. Increasing the number of approaches that an agency takes to a given issue increases the effective "population size" of regulatory approaches. This increase would present more policy variation to any selective pressures in play and allow better approaches to arise more often. Although at first blush this would seem to cut against some core benefits of agencies-regulatory certainty and uniform application of rules, for example - many agencies already exhibit a highly diverse set of responses to any given regulatory question. For example, Professor Dave Owen provides a detailed account of significant regional variation across the U.S. Army Corps of Engineers' regulatory programs and notes that such variation can produce new regulatory innovations more quickly than a centralized, unitary approach. ${ }^{409}$ Provided that an agency focuses on utilizing the policy innovations that develop this method of effectively increasing the population of regulations subject to selection, that same agency can increase the rate of evolution of these laws. ${ }^{410}$ Notably, regional variation produced both the Safe Harbor Program and the original experimental population designations. As other commentators have noted, "sociolegal regimes that favor less hierarchical, flatter, and more decentralized power structures will tend to outperform competing models in that respect." ${ }^{111}$ Professor Ruhl's cogent analysis voices a strong concern that " $[\mathrm{t}]$ he centralized federal regulatory state, in other words, is taking the 'sex' out of democracy and thus impeding the adaptiveness of the American sociolegal system." 412 Although, as suggested by Owen's piece, this concern may be overblown, Professor Ruhl is certainly correct that less centralization would allow for better exploration of the evolu-

408. Richard Frankham, Relationship of Genetic Variation to Population Size in Wildlife, 10 Conservation Biology 1500, 1507 (1996) ("Theoretical predictions that reductions in population size reduce genetic variation have been amply verified."); Thomas et al., supra note 398 , at 1178 (noting that "the fixation of adaptive substitutions is expected to be more efficient in larger populations").

409. Dave Owen, Regional Federal Administration, 63 UCLA L. Rev. 58, 108-110 (2016).

410. Id. at 109 (arguing that "[r]eplication and scaling up are key components of any successful program of policy experimentation, and an organization in which regional staff frequently talk to their counterparts elsewhere has clear advantages").

411. Ruhl, supra note 21, at 1418-19; see also Hornstein, supra note 20, at 935-36 (recognizing the need for increased experimentation in environmental law); Daniel A. Farber \& Jody Freeman, Modular Environmental Regulation, 54 Duke L.J. 795, 798-800 (2005). There is a tension between continuing experimentation and exploiting the effective approaches already in place. For a full discussion, see Hornstein, supra note 20, at 942.

412. Ruhl, supra note 21, at 1419. 
tionary landscape and should lead to the emergence of better solutions to some of our pressing administrative challenges.

Fourth, increased selective pressure also speeds adaptive evolution, ${ }^{413}$ so actions increasing the strength or frequency of selection in the administrative law realm will also speed adaption of administrative laws. One area, judicial review, is particularly able to provide stronger selection through changes in the application of Chevron doctrine. Tightening the application of Chevron's second step will ensure not only that administrative lawmaking continues to evolve, but that it also evolves toward the policy Congress intended when it created the underlying statute. A recent study found that, when circuit courts get to Chevron's second step, they defer to agencies a stunning $93.8 \%$ of the time, as compared to $39 \%$ of the time at step one. ${ }^{414}$ Because $70 \%$ of the decisions relied on step two analysis, the circuit courts approved agency statutory interpretations nearly $80 \%$ of the time. 415 Tightening step two analysis could significantly increase the force of selection in the evolution of administrative law and ensure a greater degree of directionality to that evolution. ${ }^{416}$

Courts could also heighten other kinds of selection by becoming a bit more formalistic in determining when to defer to agencies. For example, the Supreme Court has ruled "interpretations contained in policy statements [are] beyond the Chevron pale," 417 and the Administrative Procedures Act itself exempts "general statements of policy" from its rulemaking requirements. ${ }^{418}$ Nevertheless, courts routinely give policy statements Chevron deference under the Mead standard, which applies Chevron deference "when it appears that Congress delegated authority to the agency generally to make rules carrying the force of law, and that the agency interpretation claiming deference was promulgated in the exercise of that authority." 419 By replacing a bright line rule on policy statements with a hazy test, the Supreme Court creates ambiguity for stakeholders seeking to engage with agency decision-making. The Mead standard only applies in retrospect because it is based, in part, on whether the agency claims deference for the policy it seeks to rely on. During agency policymaking, stakeholders may not be able to discern whether the policy in question will be legally binding on the agency or whether it will eventually receive deference in the courts. Without this information, stakeholders cannot determine how much time and energy to invest in the

413. See, e.g., Alistair S. Jump \& Josep Penuelas, Running to Stand Still: Adaptation \& the Response of Plants to Rapid Climate Change, 8 Ecology Letters 1010, 1010-11 (2005).

414. Barnett \& Walker, supra note 103 , at 6.

415. Id.

416. See Ruhl, supra note 66, at 925 ("Chevron creates an anti-majoritarian force within agencies and allows them to move policy away from the actual policy intended by Congress.").

417. United States v. Mead Corp., 533 U.S. 218, 220 (2001).

418. 5 U.S.C.A. $§ 553$ (b) (West 2017) ("Except when notice or hearing is required by statute, this subsection does not apply to . . . general statements of policy.").

419. Mead Corp., 533 U.S. at 226-27. 
policymaking effort. If stakeholders fail to adequately engage in policymaking based on this uncertainty, they would, in effect, reduce the selection pressure on the agency policymaking, slowing the administrative evolution of the law.

The DPS policy provides a good example of this phenomenon. The Services did not clearly indicate that they were making a rule with the force of law when they prepared the DPS policy, noting only that it would "guide the evaluation of distinct vertebrate population segments for the purposes of listing, delisting, and reclassifying under the Act." ${ }^{20}$ Even the Services' approach to the policymaking, which allowed for public comment, does not clearly indicate that the policy was, at the outset, meant to have the force of law, because the Services' public comment approach was mandated by the ESA. ${ }^{421}$ The Service considered promulgating the policy as a rule, but ultimately rejected that approach. ${ }^{422}$ Only later, when the Services sought and received Chevron deference during review of the DPS policy, ${ }^{423}$ was the importance of subjecting the draft policy to strong selection pressure truly clear to stakeholders, and clarity only after the rulemaking does not give stakeholders the impetus to comment they need at the outset of policy making. For better public participation, and the improved opportunity for administrative evolution of the law that implies, courts should require agencies to clearly identify at the outset any policymaking that will have the force of law or they otherwise believe will merit Chevron deference. Agencies should not be able to hide new rules as mere informal policymaking.

Finally, this theoretical approach should provide some reassurance to commentators who have argued that the advent of the administrative state has ended (or at least greatly slowed) the evolutionary improvement of American law. Professor Ruhl argues "the administrative state, now that it has reached an advanced, mature state of power, is simply too rigid and thus not equipped to work hand in hand with a dynamic, adapting democracy." 424 His broader argument suggests that administrative takeover of legislative functions has effectively ended much of the evolution of law. But, to quote the fictional scientist Ian Malcolm from the popular film Jurassic Park, "[i]f there is one thing the history of evolution has taught us, it's that life will not be contained. Life breaks free. It expands

420. Draft Policy Regarding the Recognition of Distinct Vertebrate Population Segments Under the Endangered Species Act; Request for Public Comment, 59 Fed. Reg. 65,884, 65,884-01 (Dec. 21, 1994).

421. See 16 U.S.C. $\$ 1533(\mathrm{~h})(2)$ (2012) (requiring the Services to publish in the Federal Register, any guidelines on "criteria for making findings ... with respect to [listing] petitions."); see also id. § 1533(h)(4) (stating that the Services have to "provide to the public notice of, and opportunity to submit written comments on, any guideline (including amendment thereto) proposed to be established under this subsection.").

422. Nw. Ecosys. All. v. U.S. Fish \& Wildlife Servs. 475 F.3d 1136, 1143 n.6 (9th Cir. 2007).

423. Id. at 1143 ("[T]he DPS Policy is entitled to Chevron deference."); Maine v. Norton, 257 F. Supp. 2d 375, 385 (D. Me. 2003) ("Mead dictates that the Joint DPS Policy be considered under the Chevron standard.").

424. Ruhl, supra note 21, at 1478. 
to new territories. It crashes through barriers. Painfully, maybe even . . . dangerously . . .." ${ }^{425}$ Evolution of the law continues within the administrative state.

The evolutionary theory of administrative law suggests many additional avenues for research. For example, biology offers a range of weird and wonderful examples of evolution gone awry, and many of these examples may be closely analogous to legal evolutions.

Some organisms exhibit conspicuous traits that reduce their odds of survival, but nevertheless increase their odds of passing along their genetic materials-consider the male peacocks' tail, ${ }^{426}$ bright colors on male fish, or elaborate antlers on deer. These are examples of sexual selection. In the example of the peacock, peahens "show a strong mating preference for males with elaborate trains," 427 even though those peacocks have a harder time surviving due to the very elaborate tails that make them more attractive. The very trait that is attractive and leads to successful reproduction makes the peacock less likely to survive. This phenomenon could show up in legal evolution as well-agencies may be more likely to choose from the pool of potential rules they think most likely to be politically attractive, not those most likely to accomplish the goals of the statute. If an agency is too responsive to prevailing selective pressures and those pressures conflict with the underlying statute, the agency may, over time, produce rules that, while attractive, are ill conceived for accomplishing their purpose. Perhaps this would correlate to agency capture, where the engine to administrative evolution is coopted by administrators seeking to please the regulated community.

In another form of evolutionary intrigue, evolutionary arms races can produce outcomes with significant costs for relatively innocent bystanders. In an evolutionary arms race, two competing organisms continue to evolve to outpace each other, with neither side ever really winning. For example, a plant population evolving toxins (like nicotine, for example) that kill or dissuade herbivores inadvertently selects for herbivores resistant to the toxins, and then the plants continue to evolve stronger toxins, in a never-ending escalation. ${ }^{428}$ The classic version of the evolutionary arms race comes from studies on newts and garter snakes. The newts produce tetrodotoxin, which can kill a human, but many populations of garter snakes are able to eat the newts with no ill effects. ${ }^{429}$ The newts continue to get more toxic, and the garter snakes continue to evolve

425. JuRASSIC PARK (Universal Pictures 1993).

426. Marion Petrie et al., Variation in the Peacock's Train Shows a Genetic Component, 135 Genetica 7, 7-10 (2009).

427. $I d$.

428. University of California Museum of Paleontology, The Arms Race, UnderstandING EvOLUTION, https://evolution.berkeley.edu/evolibrary/article/armsrace_01 [http://per ma.cc/MZ7Q-BVW6] (last visited Jan. 6, 2019).

429. Rachel Feltman, How an Evolutionary Arms Race with Snakes Turned Newts Super Toxic, WASH. Post (June 10, 2016), https://www.washingtonpost.com/news/speak ing-of-science/wp/2016/06/10/how-an-evolutionary-arms-race-with-snakes-turned-newtssuper-toxic/?utm_term=.f43317e2ac93 [http://perma.cc/G3HG-5DZR]. 
greater tolerance, but other species caught in the newts' toxic crossfire are unlikely to survive. Analogies to the arms race are easy to conceive in administrative law. Consider a case where the EPA seeks to eliminate a source of pollution, but the pollution producers adopt ever more creative ways to shift that pollutant out from under the existing regulatory regime. The EPA changes and expands the regime, and the producers again shift their strategy. Over time, the regulatory structure grows immense and unwieldy, with draconian punishments and intense records requirements. The structure grew out of the arms race between the EPA and the producer, but innocent bystanders who run afoul of the labyrinthine regulatory structure pay the price. Others have suggested some additional evolutionary oddities worth considering, including preadaptation; cases where one selection for one trait necessarily carries along other, less desirable traits; and maladaptation due to evolutionary lag time in a rapidly changing environment. ${ }^{430}$ These may offer fruitful paths for additional research.

Finally, additional research using this approach should address other super statutes and could beneficially compare administrative evolution of those statutes to administrative rulemaking under statutes that the legislature changes more frequently, to determine how this affects the rate of administrative evolution of the law.

\section{CONCLUSION}

Evolutionary analysis of the law has a longstanding place within legal academia and has provided a productive perspective for centuries of inquiry. As we have transitioned to an administrative state, however, we have lost this evolutionary perspective on the law. This article updates evolutionary legal theory for the administrative age, exposing for analysis much of implicit understanding of how administrative legal change occurs. Through three case studies, we see administrative law evolving in response to selective pressure from changing science, changing political climates, and changing social needs or desires. The case studies share a common pattern-presentation of varying policy options, selection acting on those options until the agency selects one or two policy choices, and then new policy possibilities arising that inherit vestiges of the past agency actions. Variation, selection, and inheritance. The pattern mimics biological evolution in ways that usefully inform our perspective on administrative law. Future research should consider the applicability of evolution to other realms of administrative law, including both fields beyond environmental law and administrative law actions beyond rulemakings. Such analysis will aid in determining the broader applicability of the evolutionary metaphor to administrative law.

430. See generally Rodgers, supra note 60, at 56-60. 